OPEN ACCESS

Edited by:

Paterno Castillo,

University of California, San Diego,

United States

Reviewed by:

Zi-Fu Zhao,

University of Science and Technology

of China, China

Simone Tommasini,

University of Florence, Italy

*Correspondence:

Kwan-Nang Pang

knpang@earth.sinica.edu.tw

Abdolnaser Fazlnia

a.fazInia@urmia.ac.ir

tORCID:

Kwan-Nang Pang

orcid.org/0000-0003-0369-395X

Specialty section:

This article was submitted to

Petrology,

a section of the journal

Frontiers in Earth Science

Received: 01 May 2020

Accepted: 29 July 2020

Published: 21 August 2020

Citation:

Pang K-N, Fazlnia A, Ji W-Q,

Jamei S and Jafari A (2020)

Petrogenesis of the Late Oligocene

Takht batholith, Southeastern Iran:

Implications for the Diachronous

Nature of the Arabia-Eurasia Collision.

Front. Earth Sci. 8:354.

doi: 10.3389/feart.2020.00354

\section{Petrogenesis of the Late Oligocene Takht batholith, Southeastern Iran: Implications for the Diachronous Nature of the Arabia-Eurasia Collision}

\author{
Kwan-Nang Pang ${ }^{1 * t}$, Abdolnaser Fazlnia ${ }^{2 *}$, Wei-Qiang $\mathrm{Ji}^{3}$, Susan Jamei ${ }^{2,4}$ and \\ Amin Jafari2,5
}

\author{
1 Institute of Earth Sciences, Academia Sinica, Taipei, Taiwan, ${ }^{2}$ Department of Geology, Urmia University, Urmia, Iran, ${ }^{3}$ State \\ Key Laboratory of Lithospheric Evolution, Institute of Geology and Geophysics, Chinese Academy of Sciences, Beijing, \\ China, ${ }^{4}$ Faculty of Earth Sciences, Shahid Beheshti University, Tehran, Iran, ${ }^{5}$ Department of Geology, Faculty of Natural \\ Sciences, University of Tabriz, Tabriz, Iran
}

Zircon U-Pb age, mineral compositional, elemental and Sr-Nd isotopic data are documented for intermediate to felsic rocks in the Takht batholith, a Late Oligocene igneous complex in the southeastern segment of the Urumieh-Dokhtar belt, Iran, to investigate magma genesis in the context of regional tectonics. A large part of the magmatic belt formed by northward subduction of the Neotethys before the ArabiaEurasia continental collision. Zircon U-Pb age data indicate the batholith crystallized at $\sim 25 \mathrm{Ma}$, an age consistent with previous results. Geochemical data indicate that the rocks share features typical of calc-alkaline magmas and I-type granitoids. The least evolved magma inferred from the data has basaltic andesite composition, consistent with either of the following origins: (i) a partial melt of the mantle followed by differentiation, or (ii) a partial melt of the lower crust. With increasing $\mathrm{SiO}_{2}$, $\left({ }^{87} \mathrm{Sr} /{ }^{86} \mathrm{Sr}\right)_{25 \mathrm{Ma}}$ increases from 0.7053 to 0.7073 , and $\varepsilon \mathrm{Nd}_{25 \mathrm{Ma}}$ decreases from -0.3 to -2.9 , consistent with increasing effects of assimilation-fractional crystallization, although processes such as magma mixing and melting of heterogeneous source rocks cannot be entirely ruled out. Aluminum-in-hornblende thermometry indicates that the batholith might have emplaced at $\sim 6.5 \mathrm{~km}$ or shallower paleo-depths. Moho depth proxies $\mathrm{Sr} / \mathrm{Y}$ and $(\mathrm{La} / \mathrm{Yb})_{N}$ yield crustal thickness of $\sim 20-30 \mathrm{~km}$, showing no evidence for magma processing within thick crust. Overall, our results indicate that the Takht batholith is a Cordilleran-type batholith formed beneath a continental or transitional arc of normal crustal thickness. This is consistent with the notion that Arabia and Eurasia have collided in a diachronous manner, propagating from the northwest to the southeast since the Late Eocene-Early Oligocene.

Keywords: granitoids, geochemistry, Urumieh-Dokhtar, Arabia, Eurasia, Neotethys 


\section{INTRODUCTION}

Subduction and collision are important tectonic processes that take part in orogenic cycles. These processes not only bring together continental masses but also create and shape mountain belts, playing a key role in ocean and atmospheric circulation (Yin and Harrison, 2000; Allen and Armstrong, 2008; Jagoutz et al., 2016). Also, subduction and collision lead to development of thick crust that resists recycling, contributing to continent formation (Cawood et al., 2013; Hawkesworth et al., 2017; Moyen et al., 2017). Despite the above importance, tracking subduction and collision events in orogens is harder than generally appreciated. In a given orogenic system, there could be multiple events of subduction and collision in different time and space, superimposed and variably preserved in the geologic record. Unraveling details of the record requires studies within and across sub-disciplines of earth sciences.

In magmatic orogens, igneous record gives useful constraints on magma genesis, which could yield indirect clues in tracking subduction and collision. For example, thick lithosphere generated by collision might facilitate formation of alkaline magmas either by relatively low degrees of mantle melting (Aldanmaz et al., 2000) and/or increased influence of continentderived materials in magma genesis (Wang et al., 2017). Magmas formed over thick crust in subduction and collision zones tend to have high $\mathrm{Sr} / \mathrm{Y}, \mathrm{La} / \mathrm{Yb}$, and $\mathrm{Dy} / \mathrm{Yb}$ because of increased influence of residual garnet over plagioclase in magma genesis (Chung et al., 2003; Topuz et al., 2005; Ji et al., 2012; Goss et al., 2013; Ducea et al., 2015). For instance, Sr/Y and La/Yb of intermediate to felsic magmas have been taken as indicators of Moho depths in arcs and continental collision zones (Chapman et al., 2015; Profeta et al., 2015; Hu et al., 2017).

This study is focused on the petrology and geochemistry of the Late Oligocene Takht batholith (Fazlnia et al., 2014; Hosseini et al., 2017a), which crops out in the southeastern segment of the Urumieh-Dokhtar belt, Iran within the Arabia-Eurasia collision zone. The Late Oligocene is a critical timing in this particular collision zone because it coincides with most estimates for the age of initial collision. Here, we use zircon $\mathrm{U}-\mathrm{Pb}$ ages, mineral composition, geochemical and $\mathrm{Sr}-\mathrm{Nd}$ isotopic data to (i) describe the mineralogical and geochemical variations of different rocks from the batholith, (ii) constrain the petrogenesis of these rocks, and (iii) explore the potential implications of magma genesis in the context of regional tectonics. Our data indicate that the Takht batholith formed in an arc setting, showing no signs of any collision-induced crustal thickening. Because the Arabia-Eurasia collision has initiated at the Turkish-Iranian borderlands by the time the batholith formed, our results hint that the collision might have occurred in a diachronous manner.

\section{GEOLOGICAL BACKGROUND}

Mountain ranges of Iran are parts of the Alpine-Himalayan orogenic system. In particular, the Zagros orogen has received much attention because it formed by colliding continents of Arabia and Eurasia. The orogen consists of three subparallel, NW-SE-trending structural elements including (i) the Urumieh-Dokhtar belt, (ii) the Sanandaj-Sirjan zone, and (iii) the Zagros fold and thrust belt (Figure 1). A conventional wisdom regarding Zagros orogeny is that the Arabia-Eurasia collision has followed Neotethyan subduction from the Jurassic to the Tertiary (Berberian and King, 1981; Alavi, 1994; Hassanzadeh and Wernicke, 2016). Increasing evidence points to the Late Eocene to the Early Oligocene as the initial age of collision (Allen and Armstrong, 2008; Mouthereau et al., 2012; McQuarrie and van Hinsbergen, 2013; Gholami Zadeh et al., 2017; Koshnaw et al., 2018), along what is now the Bitlis-Zagros suture (or the Main Zagros Fault), the major tectonic boundary between the Sanandaj-Sirjan zone and the Zagros fold and thrust belt.

The Zagros orogen has an extensive igneous record, particularly focused in the Sanandaj-Sirjan zone and the Urumieh-Dokhtar belt. The latter is a $\sim 1800-2000-\mathrm{km}$-long and $\sim 50-80-\mathrm{km}$-wide belt composed mainly of volcanic and intrusive rocks of calc-alkaline and to a lesser extent tholeiitic or alkaline affinities (Berberian and Berberian, 1981; Alavi, 1994; Shahabpour, 2005, 2007; Honarmand et al., 2013, 2016; Kananian et al., 2014; Babazadeh et al., 2017; Sarjoughian et al., 2018). It is generally accepted that a large portion of the Urumieh-Dokhtar belt represents an Andean-type paleo-arc formed by northward subduction of the Neotethys beneath terranes that had accreted to the southern margin of Eurasia (Berberian and King, 1981; Alavi, 1994; Aftabi and Atapour, 2000). Neotethyan subduction might also be responsible for Eocene magmatism that affected the northwestern part of the Sanandaj-Sirjan zone (Fazlnia, 2019). In the southeastern segment of the Urumieh-Dokhtar belt where the Takht batholith crops out, published ages of igneous rocks range between $\sim 82$ and $\sim 5.4$ Ma (Chiu et al., 2013 ; Hosseini et al., 2017b), although magmatism likely peaked over the Eocene (Verdel et al., 2011).

The Takht batholith was dated at $\sim 25 \mathrm{Ma}$ using in situ zircon $\mathrm{U}-\mathrm{Pb}$ isotopic analysis on a granitic rock (Hosseini et al., 2017a). In that study, an age of $\sim 24.2 \mathrm{Ma}$ was also reported for a granodiorite porphyry associated with high-grade $\mathrm{Cu}$ mineralization at the Takht-e-Gonbad mine. These ages are consistent with not only information shown on geological maps (Khan-Nazer and Emami, 1996) but also field relations indicating that the batholith intruded Eocene strata and was cut in places by dykes with inferred Miocene ages (Dimitrijevic, 1973; Hassanzadeh, 1993; Shafiei, 2008). Yet, the hosts to other porphyry $\mathrm{Cu}$ deposits in the southwestern segment of the Urumieh-Dokhtar belt, including Sarcheshmeh and Meiduk to the northwest of the Takht batholith, appeared to have formed slightly later at the Middle Miocene (McInnes et al., 2005; Zarasvandi et al., 2018 and references therein).

The Takht batholith consists of a wide spectrum of intermediate to felsic intrusive rocks (e.g., Dargahi, 2007; Shafiei, 2008), a view ascertained during our field work. In general, the rocks tend to be richer in mafic minerals at the margin of the batholith and in felsic minerals toward its center (Figure 1). According to aerial view, the intermediate and felsic units make up about 65 and 35\%, respectively, of the exposed batholith. Although generally richer in mafic minerals, the intermediate 


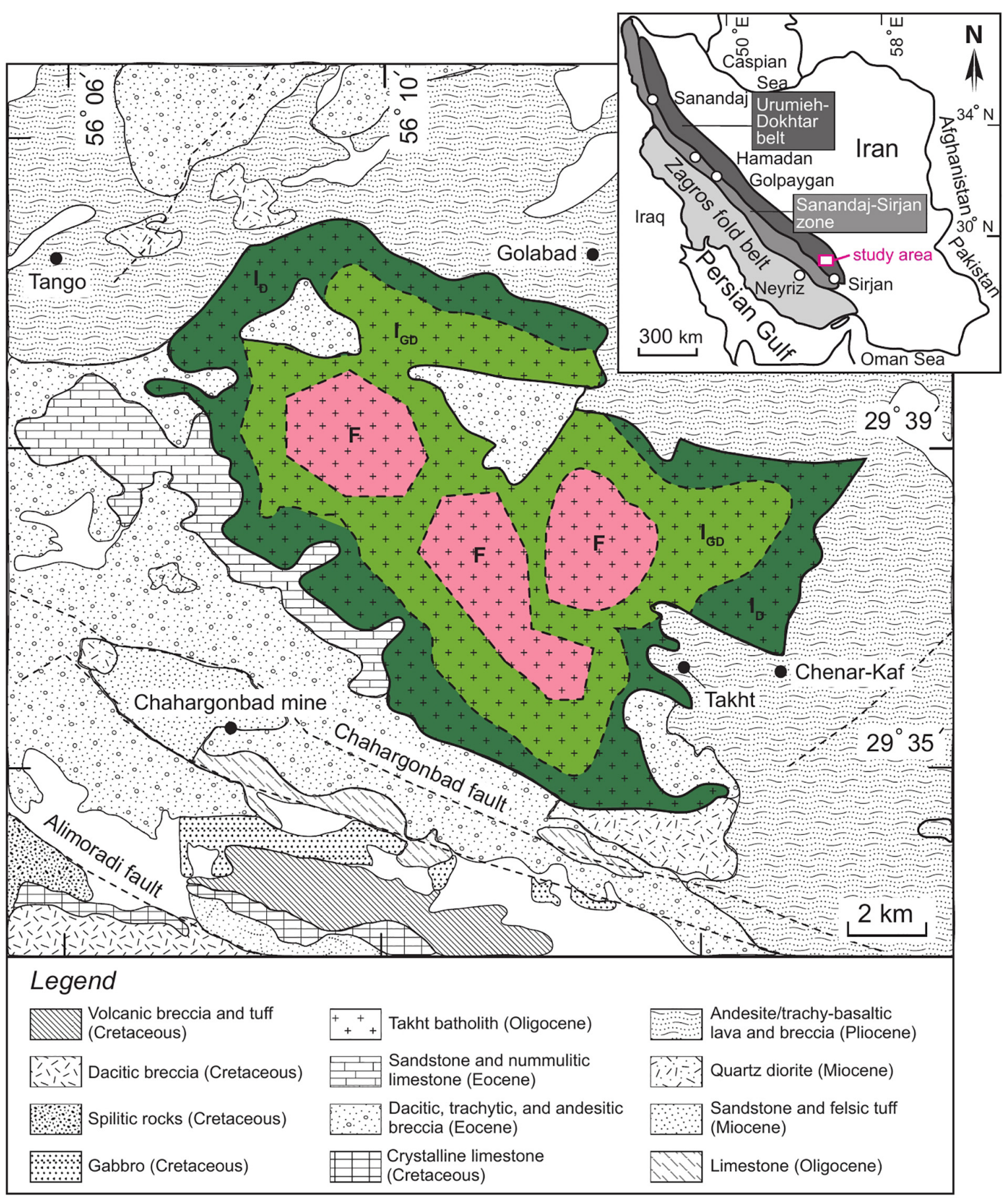

FIGURE 1 | Simplified geological sketch map showing the geology of the Takht batholith and adjacent areas, southeastern Iran (modified after Khan-Nazer and Emami, 1996). $I_{D}=$ intermediate unit dominated by diorite, $I_{G D}=$ intermediate unit dominated by granodiorite, $F=$ felsic unit. Inset shows the main tectonic units of the Zagros orogen (Stöcklin, 1968).

unit show complex contact relationships between dioritic and granitic rocks in places (Figure $\mathbf{2 A}$ ). In addition, mafic to felsic enclaves of various sizes are locally observed in outcrops (Figure 2B). Hereafter, rocks from the intermediate and felsic units are referred to as intermediate and felsic suites, respectively.

\section{PETROGRAPHY}

\section{Intermediate Suite}

Rocks of the intermediate suite are fine- to medium-grained. Granular texture is the most common (Figures 3A,B) although 


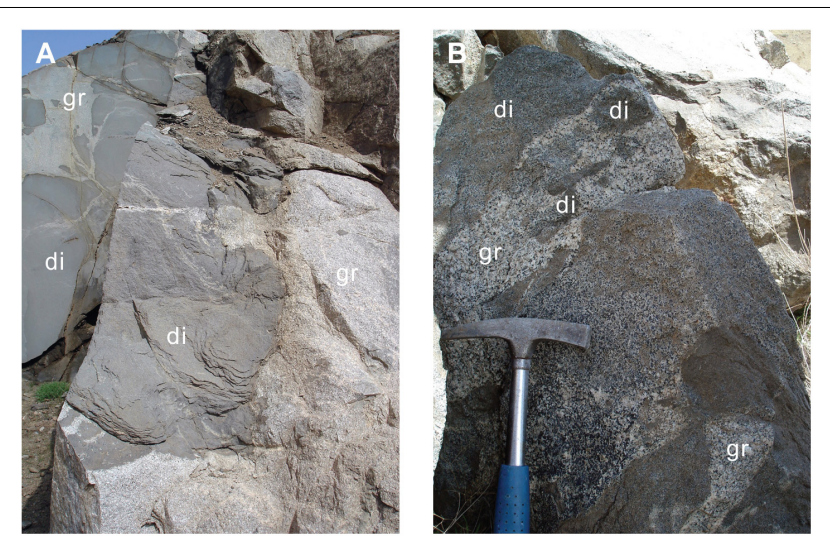

FIGURE 2 | Contact relations between dioritic (di) and granitic (gr) rocks of the Takht batholith. (A) Dioritic rock in sharp contact with and apparently cut by granitic rock; note the network of dikelets connecting to the main mass of granitic rock. (B) Centimeter-sized enclaves of diorite occur in granitic rock.

cumulate texture is observed in some samples (Figures 3C,D). Mineral assemblage comprises plagioclase $(\sim 15-55$ vol. $\%)$ and hornblende $(\sim 5-25$ vol.\%) with subordinate amounts of orthoclase ( $\sim 0-20$ vol. $\%)$, clinopyroxene $(\sim 0-15$ vol.\%), biotite $(\sim 3-10$ vol.\%), and quartz $(\sim 0-25$ vol.\%). Apatite, zircon, titanite, and $\mathrm{Fe}-\mathrm{Ti}$ oxides are common accessory minerals. Plagioclase occurs as euhedral or subhedral grains of various sizes, some of which show oscillatory zoning with margins replaced by sericite, calcite, and epidote (Figure 3D). Hornblende occurs as euhedral to subhedral grains of various sizes, and some of them form poikilitic masses enclosing grains of $\mathrm{Fe}$ Ti oxides (Figure 3A) and plagioclase (Figure 3B). Orthoclase is commonly intergrown with plagioclase, hornblende and biotite, and many orthoclase grains display perthitic texture (Figure 3E). Clinopyroxene is subhedral or anhedral, and commonly shows signs of uralitization. Biotite and quartz occur as fine to medium grains intergrown with other minerals (Figure 3E).

\section{Felsic Suite}

Rocks of the felsic suite commonly exhibit granular texture (Figures 3F-H). Mineral assemblage comprises orthoclase $(\sim 25-65$ vol.\%), quartz $(\sim 20-40$ vol.\%), plagioclase $(\sim 5-$ 15 vol.\%), hornblende $(\sim 3-10$ vol. $\%)$, and biotite $(\sim 2-5$ vol.\%). Titanite, zircon, and $\mathrm{Fe}-\mathrm{Ti}$ oxides are common accessory minerals. Orthoclase occurs as a fine- to mediumgrained, ubiquitous mineral in most monzogranites and syenogranites (Figures $\mathbf{3 F}-\mathbf{H}$ ). Perthitic texture is common in orthoclase (Figure $\mathbf{3 H}$ ). Quartz grains are subhedral with a range of sizes. Plagioclase is euhedral or subhedral, and some grains exhibit oscillatory zoning (Figure 3G). Biotite is subhedral, occurring either with hornblende or as discrete grains. Graphic intergrowths of fine-grained orthoclase and quartz are commonly observed in a subset of samples almost totally dominated by quartz and feldspar (Figure 3H).

\section{ANALYTICAL METHODS}

A large set of samples was collected from outcrops of the Takht batholith. Samples that are generally fresh and representative were selected for geochronological, mineral chemical and geochemical analyses.

Zircon was extracted from the samples by conventional methods involving heavy-liquid and magnetic separation, and hand-picking under binocular microscope. Zircon grains were mounted in epoxy, polished, and analyzed for cathodoluminescence (CL) imaging and $\mathrm{U}-\mathrm{Pb}$ isotopes by laser ablation-ICP-MS at the Beijing Quick-Thermo Science \& Technology, Co., Ltd. Details of the analytical procedures are similar as described by Ji et al. (2020). The instrument used is an ESI New Wave NWR 193UC (TwoVol2) laser ablation system connected to an Agilent 8900 ICP-QQQ. The analytical spots are $20 \mu \mathrm{m}$ in diameter. 91500 zircon and Plešovice zircon were used as primary and secondary reference materials, respectively. The latter yielded a mean age of $336.3 \pm 2.0 \mathrm{Ma}(\mathrm{MSWD}=0.8$, $n=22$ ), consistent with the recommended values within errors (Sláma et al., 2008). The zircon U-Pb age data are given in Supplementary Table 1.

Six samples were selected for electron probe microanalysis (EPMA) at the University of Kiel, Germany. Using a JEOL JXA8900 microprobe, compositions of feldspar and amphibole were determined at a probe current of 15 or $20 \mathrm{nA}$ and an accelerating voltage of $15 \mathrm{kV}$. The EPMA data are given in Supplementary Tables 2, 3 .

Sixteen samples were selected for whole-rock major and trace element analysis, which was performed at the ACME Analytical Laboratories, Canada. Samples were crushed into small chips and pulverized in an agate mill. Loss-on-ignition (LOI) was determined by heating $1 \mathrm{~g}$ of dried rock powder at $1000^{\circ} \mathrm{C}$ for $2 \mathrm{~h}$. Major element oxides were measured by $\mathrm{X}$-ray fluorescence (XRF) spectrometry and trace elements were analyzed by inductively coupled plasma-mass spectrometry (ICPMS) followed by lithium borate fusion. Precision and accuracy were monitored by replicate analyses of samples and in-house standards (Supplementary Table 4). The major and trace element data are given in Table 1.

Eight samples were analyzed for whole-rock $\mathrm{Sr}-\mathrm{Nd}$ isotopic analysis at the ACME Analytical Laboratories, Canada. A 200-400 mg aliquot of rock powder was dissolved using mixed hydrofluoric, nitric, and hydrochloric acids. Strontium was purified using cation exchange resin and $2.5 \mathrm{~N} \mathrm{HCl}$. Sample solution was loaded onto pre-outgassed and clean rhenium filaments with phosphoric acid and tantalum oxide. Strontium isotope analysis was performed using a thermal ionization mass spectrometer with five Faraday collectors in dynamic mode and ${ }^{88} \mathrm{Sr}=3.0 \mathrm{~V}$. Strontium isotopes were normalized to ${ }^{86} \mathrm{Sr} /{ }^{88} \mathrm{Sr}=0.1194$. Neodymium was purified using HDHEP-coated resin and $0.25 \mathrm{~N} \mathrm{HCl}$, and its isotopes were analyzed using multicollector ICP-MS with seven Faraday collectors after dissolution in $2 \% \mathrm{HNO}_{3}$. Neodymium isotopes were normalized to ${ }^{146} \mathrm{Nd} /{ }^{144} \mathrm{Nd}=0.7219$. The whole-rock Sr-Nd isotopic data are given in Table 2 . 

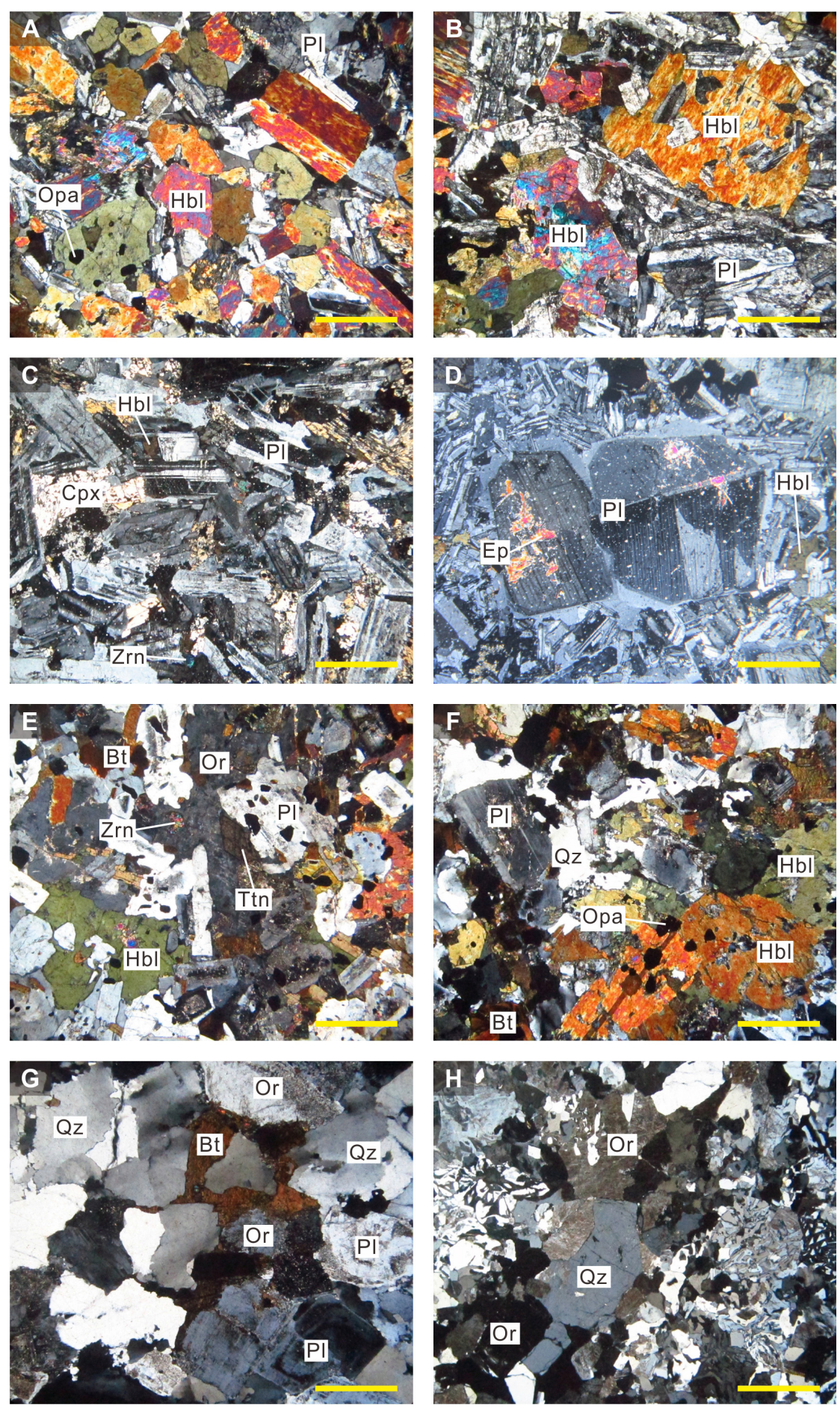

FIGURE 3 | Photomicrographs of rocks from the Takht batholith. (A) Granular texture shown by diorite consisting of interlocking grains of hornblende and plagioclase. (B) Poikilitic hornblende enclosing plagioclase in a diorite. (C) Cumulate texture shown by diorite consisting of a framework of cumulus plagioclase with intercumulus clinopyroxene and hornblende. (D) Coarse plagioclase crystals showing resorbed boundaries in a fine-grained matrix of plagioclase and hornblende in a diorite sample. (E) Granular texture shown by granodiorite consisting of interlocking grains of hornblende, biotite, plagioclase, and orthoclase. (F) Granular texture shown by monzogranite consisting of interlocking grains of hornblende, biotite, plagioclase and quartz. (G) Granular texture shown by monzogranite consisting of interlocking grains of biotite, plagioclase, orthoclase, and quartz. (H) Graphic texture, which is made up of intergrown orthoclase and quartz, shown by syenogranite. Perthite texture is observed in some orthoclase grains (upper center). All photomicrographs were taken under cross-polarized light and the yellow bars in the lower right of each frame denote length of $1 \mathrm{~mm}$. Mineral abbreviations are used after Whitney and Evans (2010), except for minerals that have no recommended abbreviations: $\mathrm{Bt}=$ biotite, $\mathrm{Cpx}=$ clinopyroxene, $\mathrm{Ep}=$ epidote, $\mathrm{Hbl}=$ hornblende, Opa $=\mathrm{Fe}-\mathrm{Ti}$ oxides, Or = orthoclase, $\mathrm{Pl}=\mathrm{plagioclase}, \mathrm{Qz}=\mathrm{quartz}, \mathrm{Ttn}=$ titanite, $\mathrm{Zrn}=$ zircon 
TABLE 1 | Geochemical data for the studied samples from the Takht batholith.

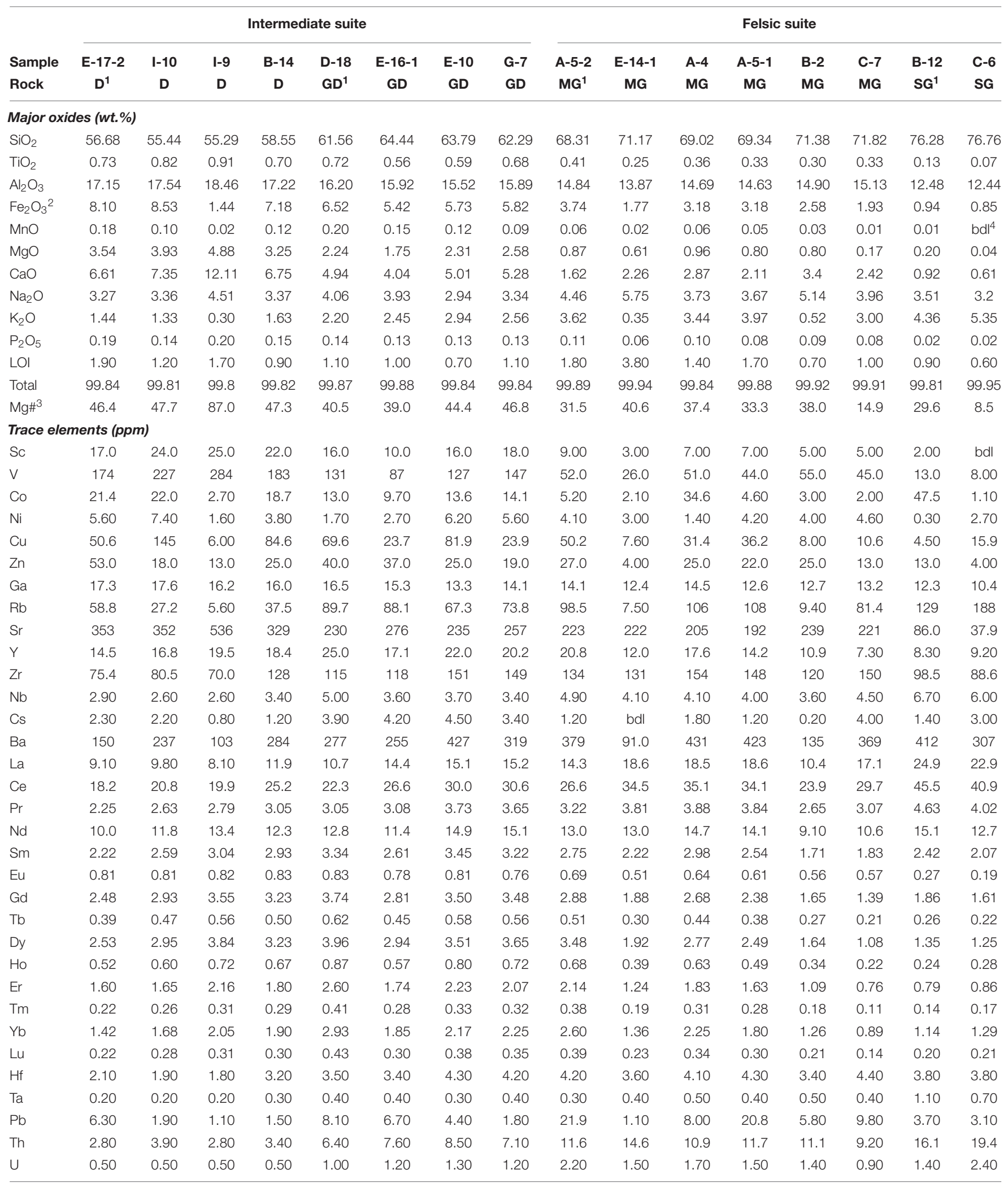

${ }^{1} \mathrm{D}=$ diorite sensu lato, $\mathrm{GD}=$ granodiorite, $\mathrm{MG}=$ monzogranite, $\mathrm{SG}=$ syenogranite. ${ }^{2}$ Total iron as $\mathrm{Fe}_{2} \mathrm{O}_{3} .{ }^{3} \mathrm{Mg} \#=\left[\mathrm{molar} 100 \times \mathrm{Mg} /\left(\mathrm{Mg}+\mathrm{Fe}{ }^{2+}\right)\right]$, assuming $10 \%$ of total iron oxide is ferric. ${ }^{4} \mathrm{bdl}=$ below detection limit. 
TABLE 2 | Sr-Nd isotopic data for a subset of the studied samples from the Takht batholith.

\begin{tabular}{|c|c|c|c|c|c|c|c|c|c|c|c|c|}
\hline Sample & Rock $^{1}$ & $\begin{array}{c}\mathbf{R b}^{2} \\
(\mathrm{ppm})\end{array}$ & $\begin{array}{c}\mathrm{Sr} \\
(\mathrm{ppm})\end{array}$ & ${ }^{87} \mathrm{Sr} /{ }^{86} \mathrm{Sr}$ & $\pm 2 \sigma_{m}^{3}$ & $\left({ }^{87} \mathrm{Sr} /{ }^{86} \mathrm{Sr}\right)_{25 \mathrm{Ma}}{ }^{4}$ & $\begin{array}{c}\text { Sm } \\
(p p m)\end{array}$ & $\begin{array}{c}\text { Nd } \\
(p p m)\end{array}$ & ${ }^{143} \mathrm{Nd} /{ }^{144} \mathrm{Nd}$ & $\pm 2 \sigma_{m}$ & $\left({ }^{143} \mathrm{Nd} /{ }^{144} \mathrm{Nd}\right)_{25 \mathrm{Ma}}$ & $\varepsilon \mathrm{Nd}_{25 \mathrm{Ma}}$ \\
\hline $\mid-10$ & $D$ & 27.2 & 352 & 0.705421 & 0.000013 & 0.7053 & 2.59 & 11.8 & 0.512612 & 0.000008 & 0.51259 & -0.3 \\
\hline D-18 & $\mathrm{D}$ & 89.7 & 230 & 0.705751 & 0.000011 & 0.7054 & 3.34 & 12.8 & 0.512598 & 0.000010 & 0.51257 & -0.7 \\
\hline E-16-1 & GD & 88.1 & 276 & 0.706785 & 0.000012 & 0.7065 & 2.61 & 11.4 & 0.512557 & 0.000010 & 0.51253 & -1.4 \\
\hline G-7 & GD & 73.8 & 257 & 0.706756 & 0.000010 & 0.7065 & 3.22 & 15.1 & 0.512512 & 0.000009 & 0.51249 & -2.2 \\
\hline$A-5-2$ & $M G$ & 98.5 & 223 & 0.706624 & 0.000010 & 0.7062 & 2.75 & 13.0 & 0.512521 & 0.000009 & 0.51250 & -2.1 \\
\hline A-4 & $M G$ & 106 & 205 & 0.707451 & 0.000012 & 0.7069 & 2.98 & 14.7 & 0.512512 & 0.000011 & 0.51249 & -2.2 \\
\hline C-7 & $M G$ & 81.4 & 221 & 0.707652 & 0.000013 & 0.7073 & 1.83 & 10.6 & 0.512495 & 0.000011 & 0.51248 & -2.5 \\
\hline B-12 & SG & 129 & 86.0 & 0.706781 & 0.000023 & 0.7053 & 2.42 & 15.1 & 0.512475 & 0.000010 & 0.51246 & -2.9 \\
\hline
\end{tabular}

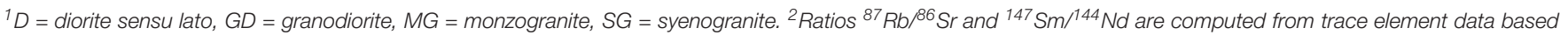

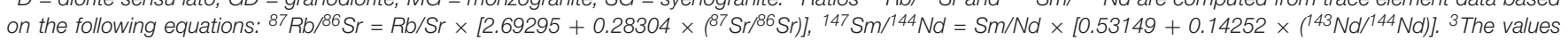

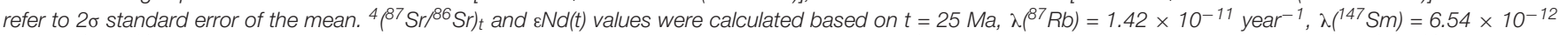

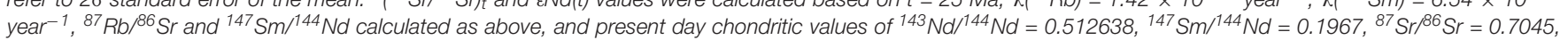
and ${ }^{87} \mathrm{Rb} /{ }^{86} \mathrm{Sr}=0.0827$ (Faure and Mensing, 2005).

\section{RESULTS}

\section{Geochemical Classification}

The geochemical data obtained are useful in characterizing rock types and magma affinity. Major element data are recalculated to millications and casted on a P-Q diagram of Debon and Le Fort (1988), on which fields for rock types are used after Bonin et al. (2020). Samples of the intermediate suite plot in fields of quartz diorite, tonalite, and granodiorite (Figure 4A); however, those classified as tonalites contain too much orthoclase to be tonalite in a strict petrographic sense. For simplicity, therefore, the former two are grouped as diorite sensu lato. Samples of the felsic suite plot above all the fields of Bonin et al. (2020) (Figure 4A). Two samples are classified as syenogranite based on relatively low molar $[\mathrm{K}-(\mathrm{Na}+\mathrm{Ca})]$ compared with the others, which are all grouped as monzogranite. This classification, although imperfect, appears justified with respect to petrographic observations (Figure 3). Besides, all samples display calc-alkaline affinity on a binary diagram of modified alkali lime index (MALI) versus $\mathrm{SiO}_{2}$ (Figure 4B). In addition, samples of the intermediate suite are metaluminous, whereas those of the felsic suite are either metaluminous or slightly peraluminous (Figure 4C). This feature, together with the occurrence of hornblende and titanite in the majority of samples, indicates an affinity to I-type granites (Chappell and White, 1974).

\section{Zircon U-Pb Geochronology}

Most zircon grains in sample I-12 (diorite) are euhedral and prismatic, showing simple oscillatory zoning typical of igneous zircon. According to Corfu (2013), igneous zircon commonly has $\mathrm{Th} / \mathrm{U}$ greater than 0.2 . Relatively high $\mathrm{Th} / \mathrm{U}$ of zircon grains in sample I-12 $(\sim 0.5-1.1)$ is thus consistent with an igneous origin (Supplementary Table 1). Nineteen spot analyses yield a mean ${ }^{206} \mathrm{~Pb}^{*} / 238 \mathrm{U}$ age of $26.2 \pm 0.6 \mathrm{Ma}$ with MSWD of 1.3 (Figures 5A,B). While zircon grains in sample E-15 (monzogranite) are also prismatic, euhedral form is less common. Oscillatory zoning is evident from CL images for most grains, yet zoning pattern appears complex for some grains. The igneous origin of the grains is indicated by relatively high $\mathrm{Th} / \mathrm{U}(\sim 0.4-1.9)$ (Supplementary Table 1 ). Twenty spot analyses yield a mean ${ }^{206} \mathrm{~Pb}^{*} / 238 \mathrm{U}$ age of $25.2 \pm 0.4$ Ma with MSWD of 1.18 (Figures 5C,D). In summary, the zircon U-Pb data support a crystallization age of the Takht batholith at $\sim 25 \mathrm{Ma}$, consistent with earlier age results reported by Hosseini et al. (2017a).

\section{Mineral Composition}

Compositions of plagioclase and orthoclase are given in Supplementary Table 2. For samples of the intermediate suite, most analyzed feldspar grains are plagioclase $\left(\mathrm{An}_{37-55}\right)$, plotting in the fields of labradorite and andesine on a ternary feldspar diagram (Figure 6A). The anorthite content of the plagioclase appears to vary negatively with $\mathrm{K}_{2} \mathrm{O}$, which ranges from about 0.2 to 0.8 wt.\%. The $\mathrm{FeO}_{\mathrm{T}}$ content ranges from about 0.2 to $0.7 \mathrm{wt} \%$, showing no correlation with anorthite content. For samples of the felsic suite, the feldspar displays substantial compositional variations. For example, a monzogranite sample has plagioclase with $\mathrm{An}_{46}$ composition, whereas a syenogranite sample contains coexisting plagioclase $\left(\mathrm{An}_{12}\right)$ and orthoclase (Figure $\mathbf{6 A}$ ). The $\mathrm{BaO}$ content of the orthoclase is about $0.4 \mathrm{wt} . \%$.

Compositions of amphibole are given in Supplementary Table 3. All analyzed amphibole grains can be classified as magnesiohornblende (Figure 6B). For samples of the intermediate suite, amphibole displays relatively restricted variations in $\mathrm{TiO}_{2}(\sim 1.2-2.4$ wt.\%), $\mathrm{CaO}(\sim 10.6-11.8$ wt.\%), and $\mathrm{Na}_{2} \mathrm{O}\left(\sim 1.4-2.0\right.$ wt.\%). In contrast, its $\mathrm{Al}_{2} \mathrm{O}_{3}(\sim 6.6-$ 10.4 wt.\%), $\mathrm{FeO}_{\mathrm{T}}(\sim 11.0-16.6$ wt.\%), and $\mathrm{MgO}(\sim 11.7-$ 15.0 wt.\%) vary over a range of several weight percent. Magnesium number of the amphibole ranges from about 67 to 81, showing no correlations with the above major elements. For samples of the felsic suite, amphibole is characterized by relatively high $\mathrm{SiO}_{2} \quad(\sim 48.2-48.5$ wt.\%), and relatively low $\mathrm{TiO}_{2}\left(\sim 0.7-1.1\right.$ wt.\%), $\mathrm{Al}_{2} \mathrm{O}_{3}(\sim 4.0-6.5$ wt.\%), and $\mathrm{Na}_{2} \mathrm{O}(\sim 0.8-1.3$ wt.\%). Yet, amphibole in both intermediate and felsic suites have overlapping ranges in Mg\# (Figure 6B). 

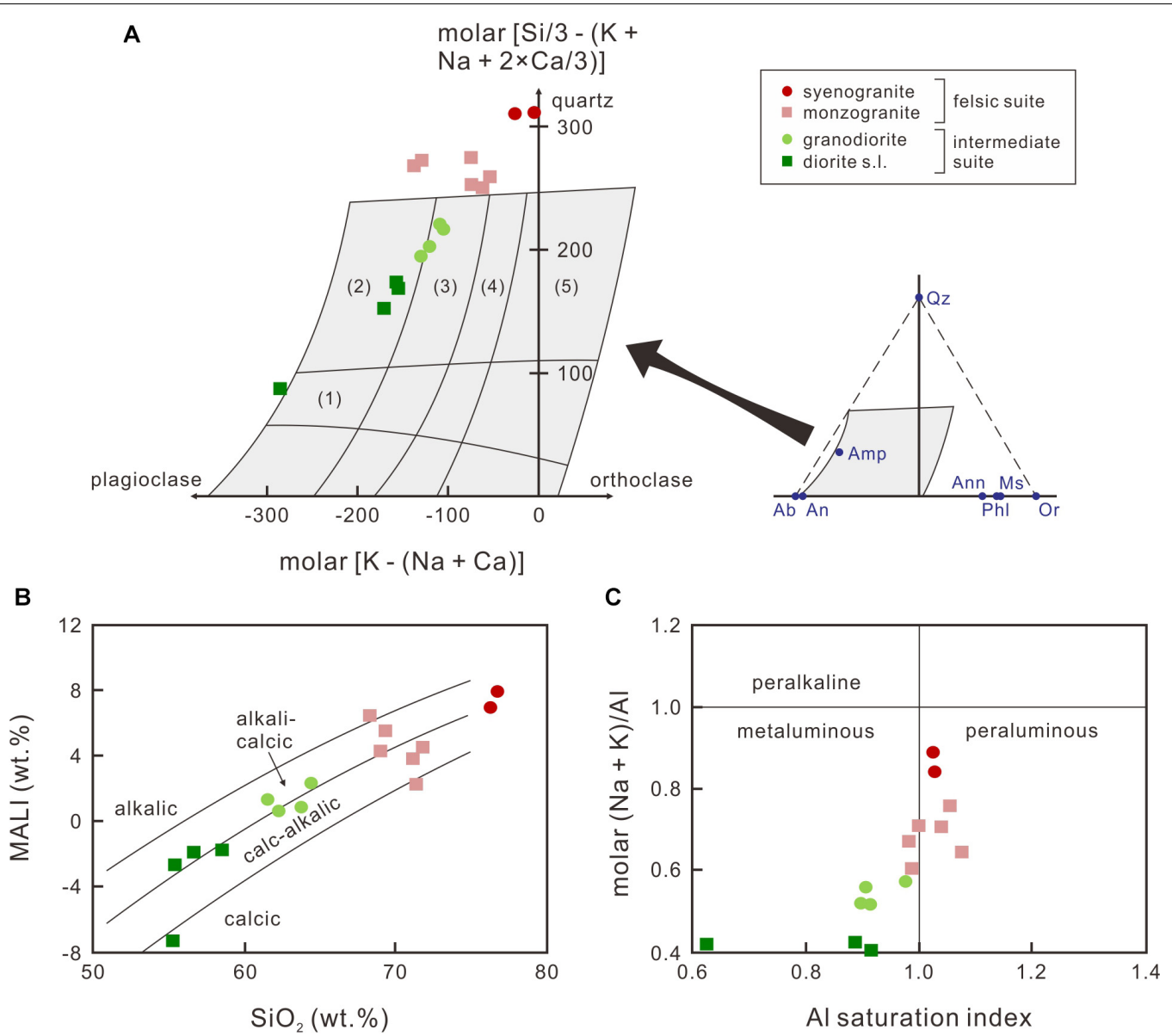

FIGURE 4 | Geochemical classification for the studied samples. (A) The P-Q diagram based on millications (Debon and Le Fort, 1988). Fields for selected rock types are after Bonin et al. (2020), including: (1) quartz diorite, (2) tonalite, (3) granodiorite, (4) monzogranite, (5) granite and syenogranite. (B) Covariation of MALI and $\mathrm{SiO}$. Solid lines separating different series are after Frost et al. (2001). (C) Covariation of molar (Na + K)/Al and aluminum saturation index.

\section{Whole-Rock Geochemistry}

The studied samples have variable $\mathrm{SiO}_{2}$ contents from $\sim 55$ to $\sim 76$ wt.\% in the following order: diorite sensu lato $<$ granodiorite $<$ monzogranite $<$ syenogranite (Table $\mathbf{1}$ ). As shown in Figure 7, the studied samples display continuous trends in the Harker diagrams. Most major elements, including $\mathrm{TiO}_{2}$, $\mathrm{Al}_{2} \mathrm{O}_{3}, \mathrm{Fe}_{2} \mathrm{O}_{3} \mathrm{~T}, \mathrm{MgO}, \mathrm{CaO}$ and $\mathrm{P}_{2} \mathrm{O}_{5}$, decrease with increasing $\mathrm{SiO}_{2}$ (Figures 7A-F). The combined concentrations of $\mathrm{Na}_{2} \mathrm{O}$ and $\mathrm{K}_{2} \mathrm{O}$ show an increasing trend with $\mathrm{SiO}_{2}$ (Figure 7G), excluding two monzogranites with low $\mathrm{K}_{2} \mathrm{O}$ contents (samples E-14-1 and B-2, Table 1). The above trends are consistent with fractionation of ferromagnesian silicates, plagioclase, $\mathrm{Fe}-\mathrm{Ti}$ oxides (and/or titanite) and apatite in generating the major element variations. Covariations of minor or trace elements and $\mathrm{SiO}_{2}$ provide additional clues into the probable fractionated phase(s). Decreasing trends of $\mathrm{V}$ and $\mathrm{Sr}$ with increasing $\mathrm{SiO}_{2}$ (Figures 8A,B) are consistent with fractionation of $\mathrm{Fe}-\mathrm{Ti}$ oxides and plagioclase. Yttrium increases with $\mathrm{SiO}_{2}$ in the intermediate suite and plummets in the felsic suite (Figure 8C), suggesting Y-bearing accessory minerals such as xenotime might have started to fractionate from the magma at a late stage of differentiation. Zirconium exhibits a similar trend as Y (Figure 8D), consistent with zircon fractionation. Niobium, $\mathrm{La}$ and Th display increasing trends with $\mathrm{SiO}_{2}$ (Figures 8E-G), suggesting that these elements, like $\mathrm{Na}$ and $\mathrm{K}$, are incompatible during the entire course of magma differentiation.

Trace element patterns shown on primitive mantlenormalized diagrams for the intermediate suite (Figure 9A) have the following features: (i) enrichment of large-ion-lithophile elements (LILE) in the order of 30 to 100 times primitive mantle abundances, (ii) negative $\mathrm{Nb}-\mathrm{Ta}-(\mathrm{Ti})$ anomalies relative to $\mathrm{K}$ and $\mathrm{La}$, (iii) positive $\mathrm{Pb}$ anomaly, and (iv) limited fractionation between middle to heavy rare-earth elements (REEs). A diorite sample (sample I-9) has a different pattern compared with the above in having lower abundances of Rb, Ba, and $\mathrm{K}$ (Figure 9B). Generally, trace element patterns for the felsic suite share similar features as those for the intermediate suite (Figure 9C). Within the felsic suite, the syenogranites in particular have low abundances of $\mathrm{Sr}, \mathrm{P}, \mathrm{Eu}, \mathrm{Ti}$ and the heavy REE compared with monzogranites, a feature presumably related to fractionation of feldspars, Fe-Ti oxides (and/or titanite) and apatite (Figure 9C). The two monzogranites showing low $\mathrm{K}_{2} \mathrm{O}$ contents display 

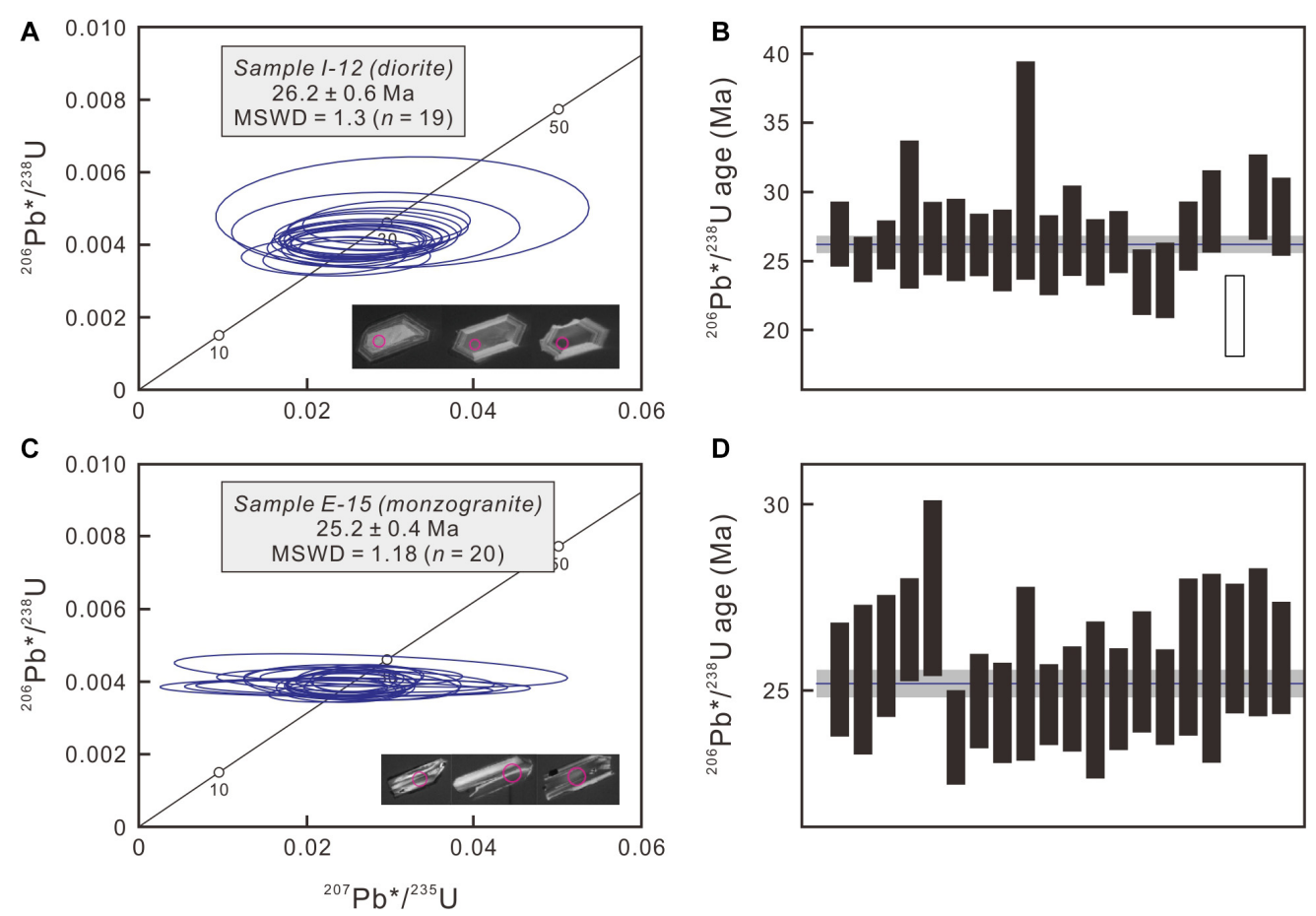

FIGURE 5 | Diagrams illustrating zircon U-Pb geochronologic results for two selected samples. (A) Wetherill concordia diagram and representative zircon CL images for sample I-12 (diorite). (B) ${ }^{206} \mathrm{~Pb}^{\star} / 238 \mathrm{U}$ age for individual spot analysis for sample $\mathrm{I}-12$ (diorite). (C) Wetherill concordia diagram and representative zircon $\mathrm{CL}$ images for sample $\mathrm{E}-15$ (monzogranite). (D) ${ }^{206} \mathrm{~Pb}^{\star} / 238 \mathrm{U}$ age for individual spot analysis for sample $\mathrm{E}-15$ (monzogranite). Red circles on $\mathrm{CL}$ images denote analyzed spots of $20 \mu \mathrm{m}$. The diagrams are generated by IsoplotR (Vermeesch, 2018). Asterisk denotes correction for unradiogenic lead by isochron regression by the Ludwig (1998) algorithm. In frames (B,D), filled bars denote analyses used for mean age calculation and empty ones do not.
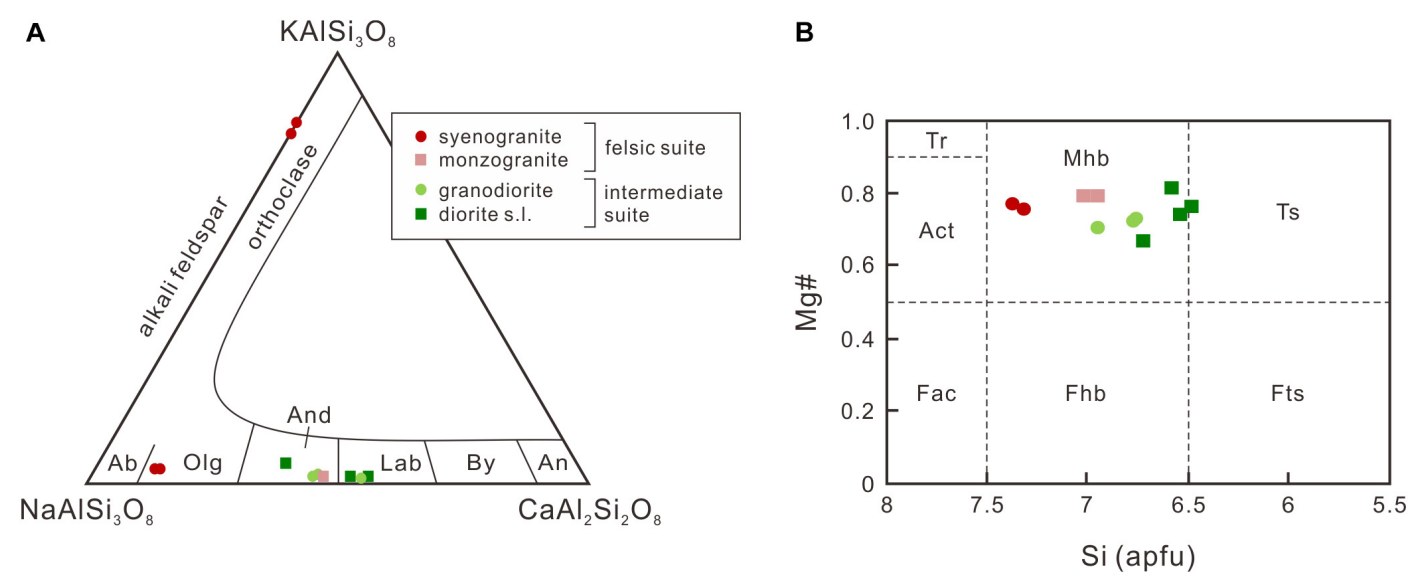

FIGURE 6 | Compositions of plagioclase and amphibole in a subset of the selected samples. (A) $\mathrm{KAISi}_{3} \mathrm{O}_{8}-\mathrm{NaAlSi}_{3} \mathrm{O}_{8}-\mathrm{CaAl}_{2} \mathrm{Si}_{2} \mathrm{O}_{8}$ ternary diagram for feldspars. (B) Mg\# versus Si binary diagram for amphibole (after Leake et al., 1997). Mineral abbreviations are used after Whitney and Evans (2010), except for minerals that have no recommended abbreviations: $\mathrm{Ab}=$ albite, $\mathrm{Act}=$ actinolite $\mathrm{An}=$ anorthite, $\mathrm{And}=$ andesine $\mathrm{By}=$ bytownite, $\mathrm{Fac}=$ ferroactinolite, Fhb $=$ ferrohornblende, Fts $=$ ferrotschermakite, Lab = labradorite, $\mathrm{Mhb}=$ magnesiohornblende, Olg $=$ oligoclase, $\mathrm{Tr}=$ tremolite, $\mathrm{Ts}=\mathrm{Tschermakite}$.

relatively low abundances of $\mathrm{Rb}$ and $\mathrm{Ba}$ in trace element patterns (Figure 9D).

The Sr-Nd isotopic data for samples chosen for analysis show limited variability. In detail, ${ }^{87} \mathrm{Sr} /{ }^{86} \mathrm{Sr}$ ranges from 0.7054 to 0.7077 , and ${ }^{143} \mathrm{Nd} /{ }^{144} \mathrm{Nd}$ ranges from 0.5125 to 0.5126 (Table 2). After age correction to $25 \mathrm{Ma}$, the isotopic data plot in the lower right quadrant of a $\mathrm{Sr}-\mathrm{Nd}$ isotope space characteristic of high time-integrated $\mathrm{Rb} / \mathrm{Sr}$ and low time-integrated $\mathrm{Sm} / \mathrm{Nd}$ relative to Bulk Silicate Earth (BSE) (Figure 10A). Using equations of Ickert (2013), the maximum errors propagated for the calculation of initial isotopic ratios are estimated to be \pm 0.0005 for $\left({ }^{87} \mathrm{Sr} /{ }^{86} \mathrm{Sr}\right)_{25 \mathrm{Ma}}$ and \pm 0.30 for $\varepsilon \mathrm{Nd}_{25 \mathrm{Ma}}$. 

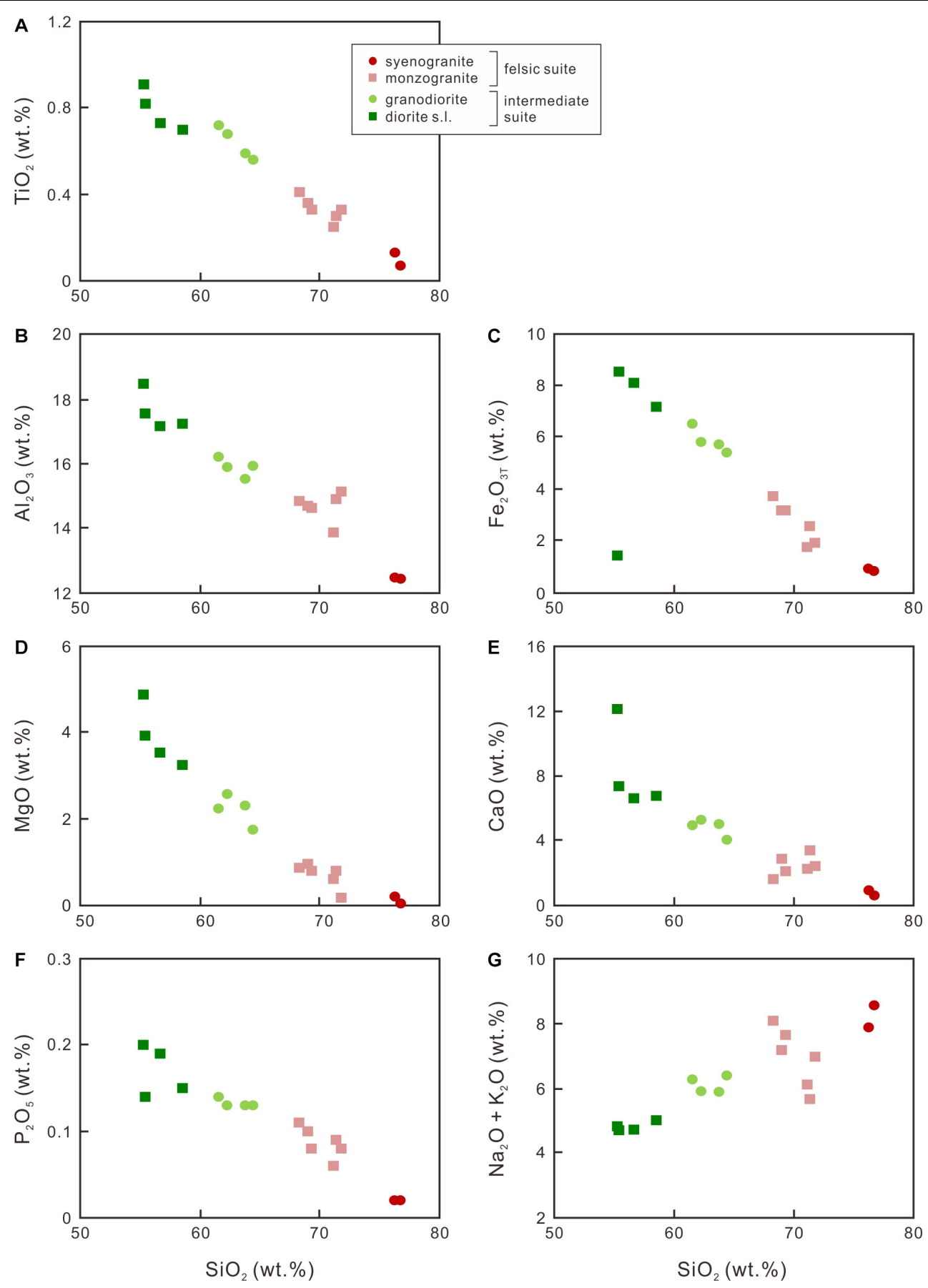

FIGURE 7 | Harker diagrams showing the variations of major element oxides against silica for the studied samples. (A) $\mathrm{TiO}_{2} ;$ (B) $\mathrm{Al}_{2} \mathrm{O}_{3} ;$ (C) $\mathrm{Fe}_{2} \mathrm{O}_{3} \mathrm{~T}$; (D) $\mathrm{MgO}$; (E) $\mathrm{CaO} ;$ (F) $\mathrm{P}_{2} \mathrm{O}_{5} ;$ (G) $\mathrm{Na}_{2} \mathrm{O}+\mathrm{K}_{2} \mathrm{O}$.

Generally, the Sr and $\mathrm{Nd}$ isotopic ratios are negatively correlated except a syenogranite (sample B-12) having lower ${ }^{87} \mathrm{Sr} /{ }^{86} \mathrm{Sr}$ than expected. A probable reason is that the $\mathrm{Sr}$ isotopic ratio of this sample is over-corrected due to post-magmatic $\mathrm{Rb}$-gain or $\mathrm{Sr}$ loss, consistent with its high $\mathrm{Rb} / \mathrm{Sr}(\sim 1.5)$. Besides, there exists a negative correlation between $\mathrm{Nd}$ isotopic ratios and $\mathrm{SiO}_{2}$ concentration (Figure 10B).

\section{DISCUSSION}

\section{Depth of Magma Emplacement}

We estimate the crustal level at which the Takht batholith was emplaced using the aluminum-in-hornblende geobarometer (Hammarstrom and Zen, 1986), a tool which was widely applied to calc-alkaline intrusive rocks (Putirka, 2016 and references 

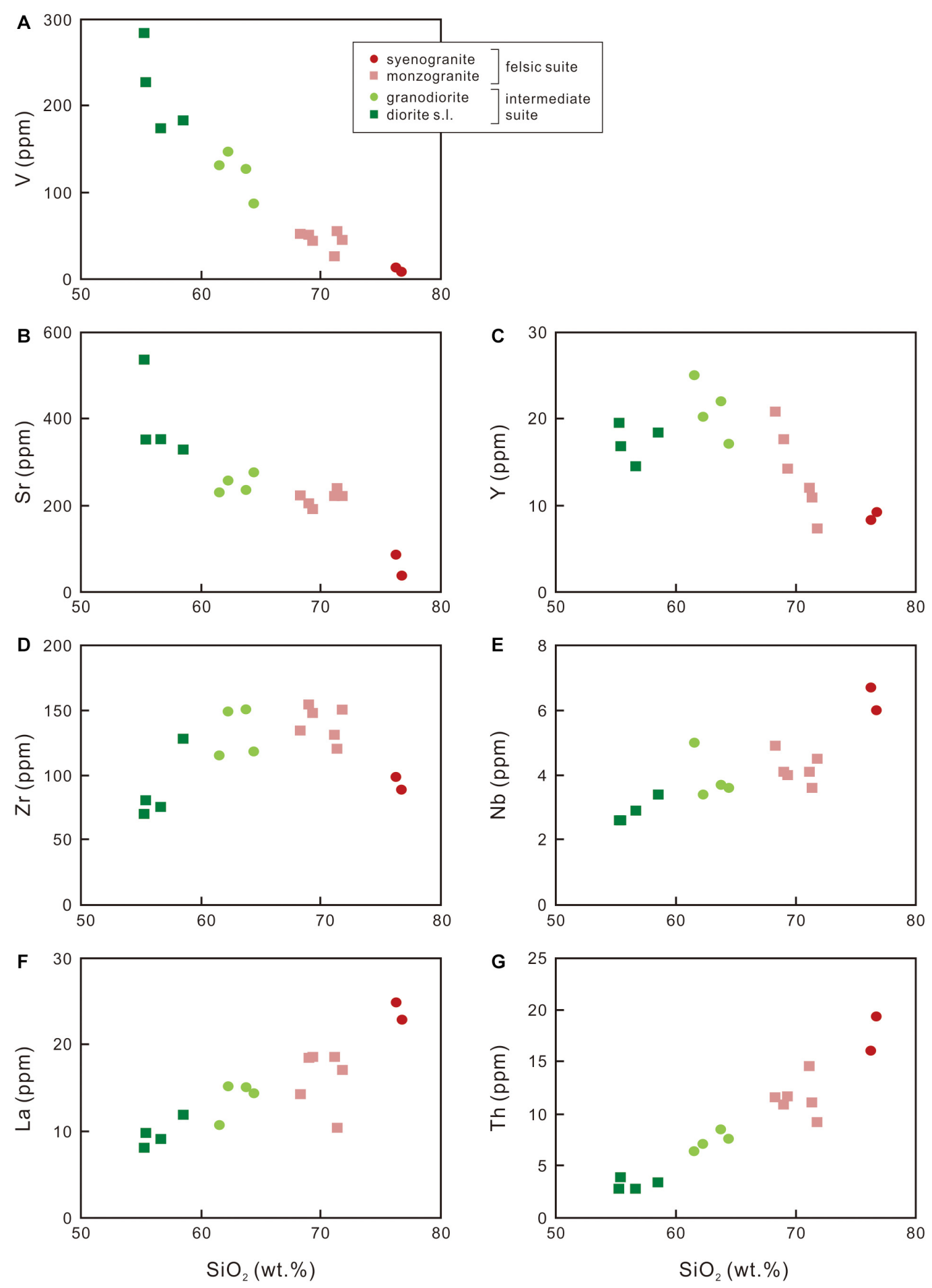

FIGURE 8 | Variations of minor or trace elements against silica for the studied samples. (A) V; (B) Sr; (C) Y; (D) Zr; (E) Nb; (F) La; (G) Th.

therein). Since its original formulation, the geobarometer was calibrated by various researchers including Hollister et al. (1987); Johnson and Rutherford (1989), Blundy and Holland (1990), Schmidt (1992), among many others. For most hornblende compositions obtained in this study (Supplementary Table 3), these calibrations yield pressure estimates between 1.3 and 5.5 $\mathrm{kbar}$, with a spread of $\sim 1-1.5 \mathrm{kbar}$ for a given hornblende analysis using different calibrations. Generally, the median of pressure resulted from different calibrations appears to follow the order: diorite sensu lato $(\sim 2.7-5.1 \mathrm{kbar})$, granodiorite $(\sim 1.8 \mathrm{kbar})$, 

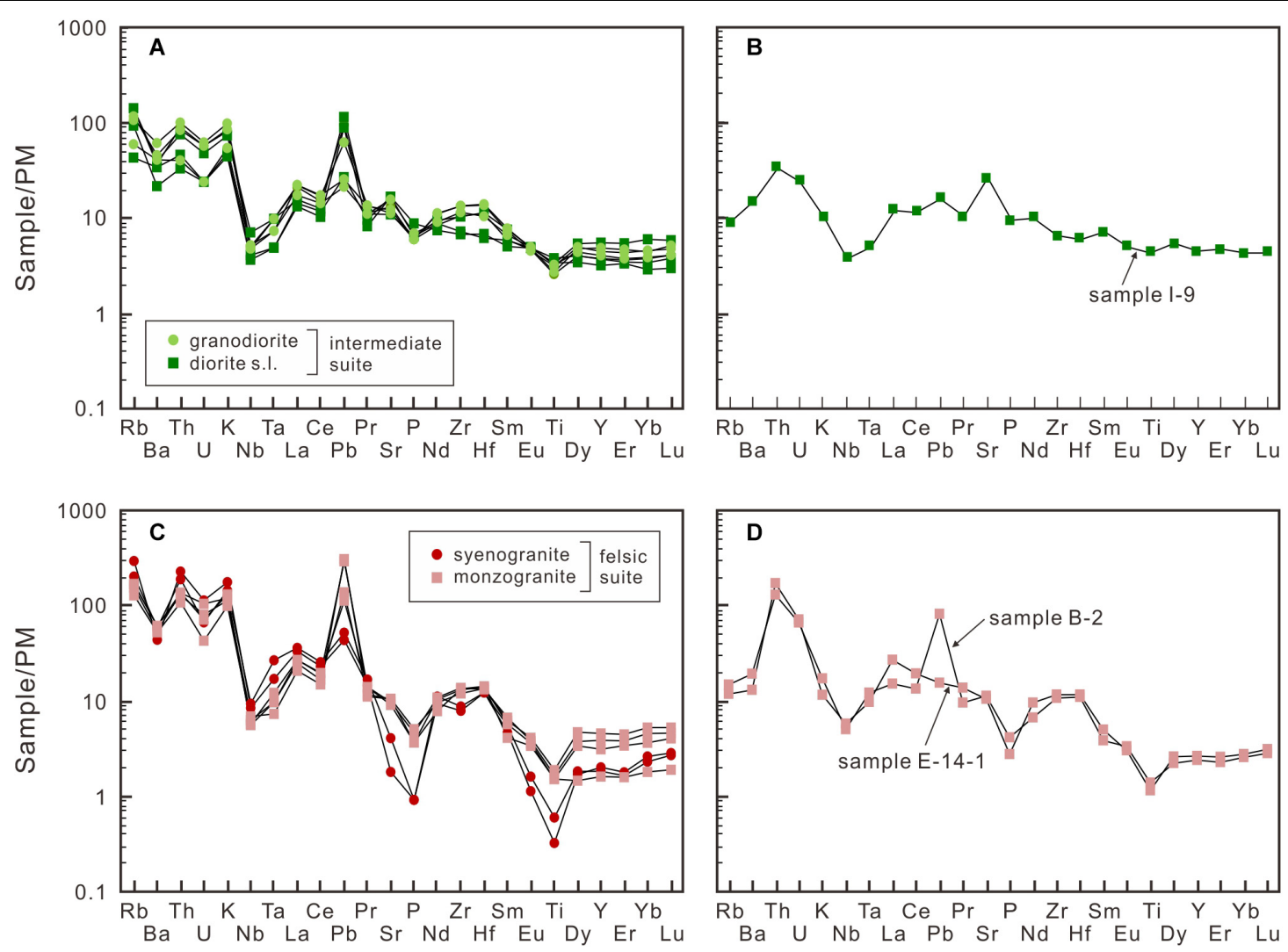

FIGURE 9 | Primitive mantle-normalized extended trace element patterns for the studied samples. (A) Intermediate suite. (B) A diorite (sample I-9) showing a different pattern from other samples of the intermediate suite. (C) Felsic suite. (D) Two monzogranites (samples E-14-1 and B-2) showing different patterns from other samples of the felsic suite. Normalizing values are after Sun and McDonough (1989).

and monzogranite $(\sim 1.5 \mathrm{kbar})$. Given the maximum distance between the mafic and felsic units in the field (Figure 1), however, it is unlikely that the entire pressure range reflects magma solidification at different paleo-depths. Instead, it is more likely that hornblende in the diorites might have formed at mid-crustal levels and were entrained by magma(s) that ascent and eventually froze at the final emplacement depth. If that is the case, the final emplacement of the Takht batholith might occur at 2 kbar or less, equivalent to about $6.5 \mathrm{~km}$ or shallower paleo-depths, an estimate close to the lower bound of $\sim 5-10 \mathrm{~km}$ made by Fazlnia et al. (2014).

\section{Petrogenetic Constraints}

It is important to evaluate the effect of alteration on the geochemical data obtained in this study, for some of these data are used to derive constraints related to magma genesis at high temperature. Petrographic observations indicate that most studied samples are essentially fresh with little or no signs of postmagmatic alteration (Figure 3). Almost all samples have LOI lower than 2 wt.\% (Table 1), except in a monzogranite (sample E-14-1) where higher LOI ( $\sim 3.8$ wt.\%) might be due to partial alteration of plagioclase to sericite as observed in thin section. Further, the trace element patterns for most studied samples are coherent (Figures 9A,C), suggesting mobilization of particular trace elements, as would be expected for extensive post-magmatic alteration, did not occur.

Sample I-9, a diorite as mentioned above, requires a special note because of its unusual major and trace element features. It has low $\mathrm{Fe}_{2} \mathrm{O}_{3}(\sim 1.4$ wt.\%), high $\mathrm{CaO}(\sim 12.1$ wt.\%) compared with other diorites (Figures 7C,E). Also, its trace element pattern is different from other diorites in showing low abundances of $\mathrm{Rb}, \mathrm{Ba}$, and $\mathrm{K}$ (Figure 9B). After a detailed petrographic check, we note several unique features: (i) a high content of plagioclase compared with the other diorites, (ii) plagioclase occurs as a framework of coarse grained crystals commonly observed in cumulates (Figure 3C), and (iii) the rare presence of hornblende and absent of biotite. Based on these observations, we suggest the unusual geochemical features of sample I9 might be related to its probable origin as a plagioclaserich cumulate.

Next, we examine probable processes responsible for generating the geochemical variations observed in the studied samples. As noted earlier, the elemental trends shown by the samples are consistent with fractionation of ferromagnesian silicates, plagioclase, $\mathrm{Fe}-\mathrm{Ti}$ oxides (and/or titanite) and apatite, presumably with zircon and/or xenotime joining the fractionating assemblage at a late stage (Figures 7, 8). Fractionation in a closed system, however, cannot explain the 


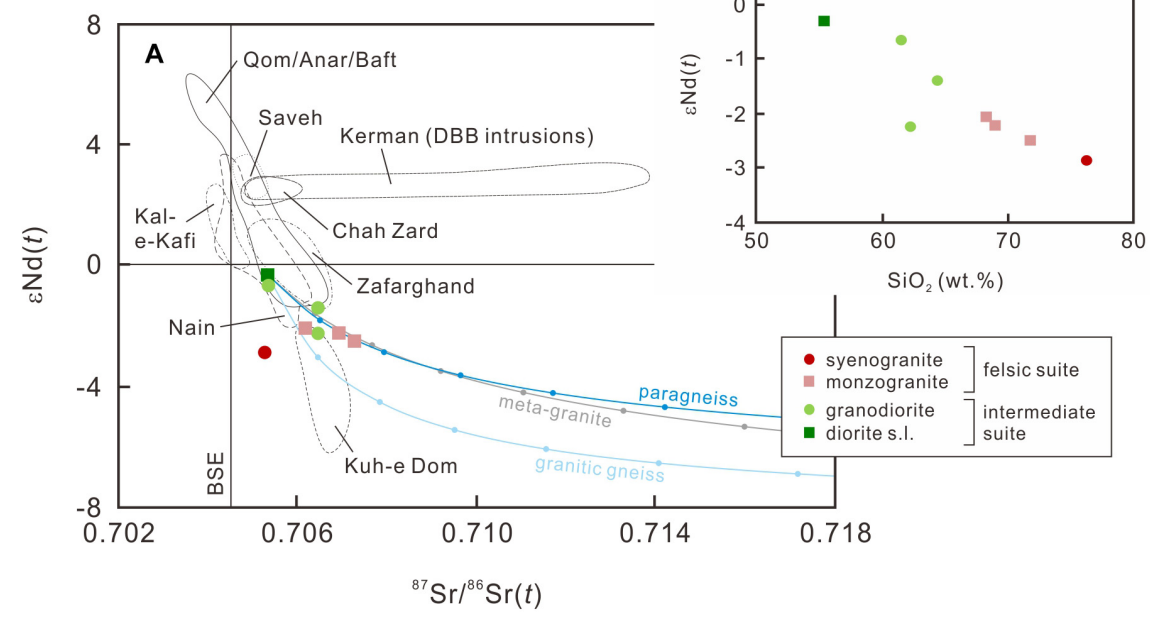

FIGURE 10 | Covariations involving Sr and Nd isotopes for the studied samples. (A) A binary diagram of $\varepsilon$ Nd versus ${ }^{87} \mathrm{Sr} / 86 \mathrm{Sr}$. (B) A binary diagram of $\varepsilon N d$ versus $\mathrm{SiO}_{2}$. Shown in frame (A) are fields of published data obtained from the Urumieh-Dokhtar belt, including Qom/Anar/Baft (Omrani et al., 2008), Kerman (DBB intrusions, Dargahi et al., 2010), Nain (Yeganehfar et al., 2013), Kuh-e Dom (Sarjoughian et al., 2012; Kananian et al., 2014), Kal-e-Kafi (Ahmadian et al., 2016), Chah Zard (Kouhestani et al., 2017), Saveh (Nouri et al., 2018), and Zafarghand (Sarjoughian et al., 2018). Also shown are AFC trajectories assuming sample I-10, which has the lowest ${ }^{87} \mathrm{Sr}^{86} \mathrm{Sr}_{25 \mathrm{Ma}}$ and $\varepsilon \mathrm{Nd}_{25 \mathrm{Ma}}$ among the studied samples, underwent concurrent fractional crystallization and assimilation of different crustal rocks from the ChahJam-Biarjmand metamorphic complex, Iran (Shafaii Moghadam et al., 2015): metagranite (sample BJ10-20, gray), paragneiss (sample CHJ09-12, deep blue), and granitic gneiss (sample CHJ09-18, light blue). The trajectories are computed using equations of DePaolo (1981) with the following parameters: crystal-liquid partition coefficients of $\mathrm{Sr}$ ( 2 for plagioclase, 0.096 for clinopyroxene, and 0.0022 for olivine) and $\mathrm{Nd}(0.14$ for plagioclase, 0.173 for clinopyroxene, and 0.001 for olivine) [compiled by Ersoy and Helvaci (2010)], a fractionating assemblage consisting of plagioclase, clinopyroxene and olivine at 6:2:2, and a ratio of assimilation rate to fractional crystallization rate of 0.5 . Dots on the trajectories denote $10 \%$ intervals for the fraction of remaining liquid.

negative correlation between $\mathrm{Nd}$ isotopes and $\mathrm{SiO}_{2}$ (Figure 10B). The trend appears to require increasing contribution of isotopically enriched materials to the magma as it became more differentiated. To model the process, we calculate assimilationfractional crystallization (AFC) trajectories using data from the ChahJam-Biarjmand metamorphic complex, which was exhumed from and likely representative of the lower to middle crust of Iran (Shafaii Moghadam et al., 2015). Three major rock types in that study are used as end-member assimilants, including a metagranite, a paragneiss and a granitic gneiss. As shown in Figure 10A, the least evolved diorite would have undergone $\sim 10-15 \%$ AFC to explain the observed Sr-Nd isotopic variations. We then explore whether the intermediate and felsic units of the Takht batholith satisfy mass balance by undertaking energy-constrained (EC)-AFC simulations (Bohrson and Spera, 2001; Spera and Bohrson, 2001) with similar compositional parameters for the initial magma and the assimilants as the classical AFC models presented above (Supplementary Table 5). The results indicate that, for all three assimilants, the initial dioritic magma would have undergone $\sim 42 \%$ differentiation (mainly by fractional crystallization) before being able to form rocks with $\mathrm{Sr}-\mathrm{Nd}$ isotopes observed in the felsic unit due to significant addition of anatectic melt from the wallrocks. Also, the mass ratios of the intermediate unit to the felsic unit predicted by these models range from 6:1 to 9:1 (Supplementary Table 6). Thus, it appears that the current exposure of these units (65 to $35 \%, \sim 2: 1)$ requires a considerable amount of dioritic rocks be hidden at a deeper level of the batholith. Another possibility is that mechanisms apart from AFC might have played a role in the formation of the felsic suite, such as crustal melting, which is discussed below.

We then consider additional magmatic processes such as mingling or mixing of magmas, which is hinted by field observations (Figures 2A,B) and complex zoning seen from plagioclase in diorites (Supplementary Figures S1-S3), even though available data point to a coherent age of $\sim 25 \mathrm{Ma}$ for the batholith (Figure 5 and Hosseini et al., 2017a). As magma mixing generates linear trends shown by covariation of elements and isotopes, one could argue that, for example, granodiorites and monzogranites are solidified products of mixing between dioritic and syenogranitic magmas (Figures 7, 8). However, mixing alone is hard to explain the kinked trends of $\mathrm{Y}$ or $\mathrm{Zr}$ versus $\mathrm{SiO}_{2}$ (Figures 8C,D), which appear to record fractionation of accessory minerals such as xenotime and zircon (Förster, 1998; Lee and Bachmann, 2014). Another possibility is that differences in rock types are results of melting heterogeneous source rocks in the crust with limited mixing of the resultant magmas. That has to imply that not only the kinked trends note above but also the $\varepsilon \mathrm{Nd}_{25 \mathrm{Ma}}-\mathrm{SiO}_{2}$ trend (Figure 10A) are fortuitous. If heterogeneous source rocks were to be melted in the crust, however, scattered data in terms of Sr-Nd isotopes and $\mathrm{SiO}_{2}$ seem to be more likely. Yet, melting heterogeneous source rocks might be responsible for second-order geochemical variations in the dataset. For example, differences in major and trace element geochemistry among the monzogranites might be related to source rocks with variable contents of K-bearing phases such as 

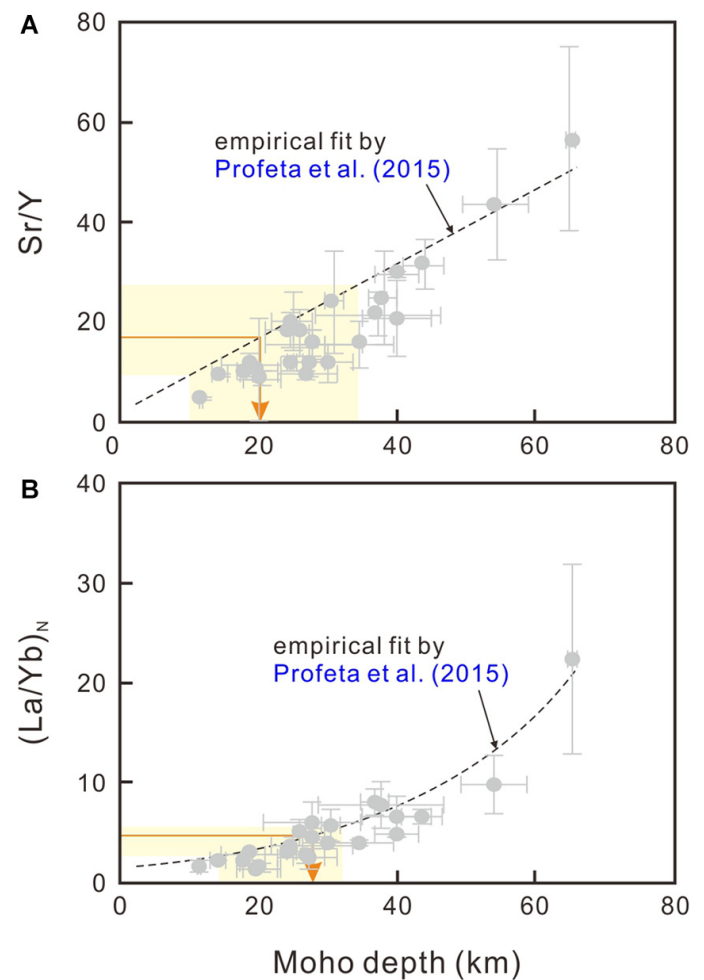

FIGURE 11 | Estimation of crustal thickness using Moho depth proxies (A) $\mathrm{Sr} / \mathrm{Y}$ and (B) $(\mathrm{La} / \mathrm{Yb})_{\mathrm{N}}$ where subscript $\mathrm{N}$ denotes normalization against $\mathrm{Cl}$ chondrite (Sun and McDonough, 1989). Dotted line denotes empirical fits of data for a given volcanic arc shown by gray symbols (Profeta et al., 2015). The yellow band and orange line denote the range and median, respectively, of data for the intermediate suite, which generally satisfy the filters proposed by Profeta et al. (2015) including ranges of $\mathrm{SiO}_{2}$ (55-68 wt.\%) and $\mathrm{MgO}$ (1-6 $w t . \%)$. If data for monzogranites are included, the median for $\mathrm{Sr} / \mathrm{Y}$ remains unchanged $(\sim 17)$ while that for $(\mathrm{La} / \mathrm{Yb})_{N}$ is slightly higher $(\sim 6.9)$.

biotite, muscovite and orthoclase (Figures 9C,D). Also, the Sr-Nd isotopic composition of the syenogranite hints derivation from source rocks that are probably different from the monzogranites (Figure 10A). In summary, we maintain that AFC exerts the dominant control of the geochemical variations observed from the samples, while processes such as mingling and mixing of magmas, and melting of heterogeneous source rocks, cannot be completed excluded.

Next, we examine the origin of the diorite sensu lato, the arguably least evolved rock type in the Takht batholith. As a group it has the highest $\mathrm{MgO}\left(\sim 3.5-4.9\right.$ wt.\%), the lowest $\mathrm{SiO}_{2}$ ( $\sim 55.3-56.7$ wt.\%) and, relative to BSE, the least unradiogenic $\mathrm{Nd}$ isotopes and the least radiogenic Sr isotopes (Figure 10A). Hosseini et al. (2017a) analyzed a range of igneous rocks related to the Takht-e-Gonbad deposit and their dataset includes a sample with basaltic composition (i.e., sample TAM12 with $\sim 6$ wt. $\% \mathrm{MgO}$ and $\sim 49$ wt. $\% \mathrm{SiO}_{2}$ ). However, that sample belongs to Eocene volcanic/volcaniclastic rocks, which were intruded by Oligocene and Miocene igneous rocks. Thus, there is no direct evidence for magmas that are more primitive than the studied diorites in the formation of the $\sim 25 \mathrm{Ma}$

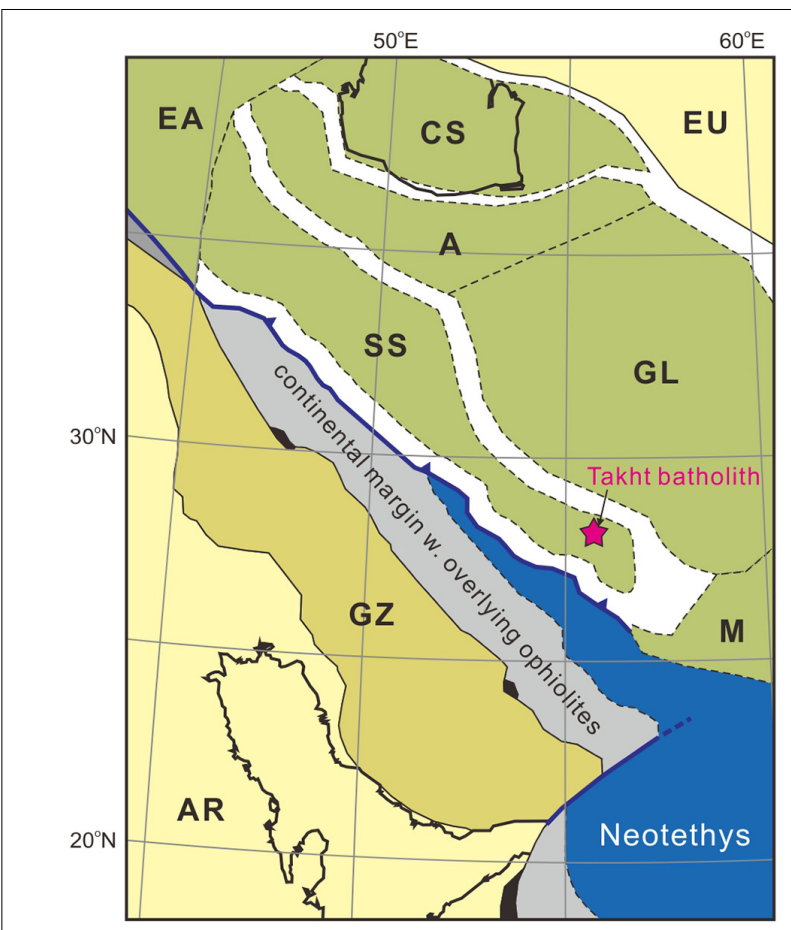

FIGURE 12 | Paleogeographic reconstruction of the Arabia-Eurasia collision zone at $\sim 27 \mathrm{Ma}$ (McQuarrie and van Hinsbergen, 2013). Gray regions denote the northeastern margin of Arabia with overlying ophiolites (shown in black, including Kermanshah, Neyriz and Semail from north to south). White regions denote areas that were shortened among continental blocks situated between Eurasia and Arabia. Red star denotes the location where the Takht batholith might have formed. $A=$ Alborz, $A R=$ Arabia, $E A=$ East Anatolia, $\mathrm{EU}=$ Eurasia, $\mathrm{GL}=$ Greater Lut, GZ = Greater Zagros, $\mathrm{M}=$ Makran, SC = South Caspian, SS = Sanandaj-Sirjan.

Takht batholith. If our inference for an intermediate parental magma is correct, then two possible origins apply. First, it might be a residual liquid of a mantle-derived magma that had undergone differentiation prior to emplacement. This explains the general lack of mafic-ultramafic rocks at the current exposure. Second, the intermediate parental magma might have a lower crustal origin. Blatter et al. (2013) demonstrated by melting experiments that intermediate magmas with similar $\mathrm{MgO}$ and $\mathrm{SiO}_{2}$ as the studied diorites could form by partial melting of hydrous arc basalts over a wide range of oxygen fugacity at lower crustal pressure. Importantly, hybrid mechanisms involving a combination of the two end-member scenarios are also permissive; for instance, mixing of lower crustal melts and variably fractionated mantle-derived magmas in zones of melting, assimilation, storage and homogenization (MASH) close to the Moho (e.g., Hildreth and Moorbath, 1988), or lower crustal hot zones (Annen et al., 2006).

\section{Tectonic Implications}

As illustrated above, the Takht batholith possesses typical subduction-related geochemical signatures (Figure 9). A straightforward explanation for these is that the Takht batholith formed in a subduction zone, an interpretation mostly 
adapted in earlier studies (Shahabpour, 2005, 2007; Shafiei et al., 2009; Mohajjel and Fergusson, 2014; Shafaii Moghadam et al., 2015; Rasouli et al., 2016). Another possibility is that the batholith formed in a setting without active subduction, for example, where subduction-modified domains of the mantle lithosphere and/or the lower crust were perturbed by processes unrelated directly to subduction (e.g., upwelling of the asthenosphere). If that is the case, variable magma types and chemistry (e.g., alkalinity, trace elements, and radiogenic isotopes) is expected because of the variety of source rocks that might be involved and the range of depths where partial melting might occur. In this study, however, we do not observe such variations and the geochemical data illustrated above are consistent in most aspects with arc magmas. Therefore, it is appropriate to consider the Takht batholith as a Cordilleran-type batholith, forming as part of a continental arc in the Late Oligocene at $\sim 25 \mathrm{Ma}$.

Our inference that the Takht batholith is of Cordilleran-type sheds indirect lights on how Arabia and Eurasia might have collided. Available data in northwestern Iran and southern Lesser Caucasus indicate that Late Oligocene magmatic rocks show geochemical features characteristic of formation over relatively thick crust, such as relatively high $\mathrm{Sr} / \mathrm{Y}$ and $\mathrm{La} / \mathrm{Yb}$ (Moritz et al., 2016; Rezeau et al., 2016, 2017). In view of growing evidence suggesting that the Arabia-Eurasia collision initiated between the Late Eocene and the Early Oligocene (Allen and Armstrong, 2008; Mouthereau et al., 2012; McQuarrie and van Hinsbergen, 2013; Gholami Zadeh et al., 2017; Koshnaw et al., 2018), these features have been interpreted in the context of collision-induced crustal thickening (e.g., Moritz et al., 2016). We note that none of the rocks in this study display such geochemical features. For instance, the ranges of $\mathrm{Sr} / \mathrm{Y}$ and $(\mathrm{La} / \mathrm{Yb})_{\mathrm{N}}$ of these rocks could be used to indicate modest crustal thickness, probably between 20 and $30 \mathrm{~km}$ (Figure 11). Here, an intriguing question is, at a given time, how the Takht batholith with an inferred arc origin can be reconciled in a tectonic setting where continental collision appeared to have started. One possibility is that collision did initiate in northwestern Iran and southern Lesser Caucasus, but not so to the southeast of the collision zone, where the Neotethys was still subducting beneath central Iran, as depicted by Chiu et al. (2013). This is consistent with paleogeographic reconstruction by McQuarrie and van Hinsbergen (2013) (Figure 12), and the view that post-collisional magmatism propagated from northwest to southeast along the ArabiaEurasia collision zone (Pang et al., 2015; Lin et al., 2020). While we remain open to other possible tectonic scenarios that could explain the aforementioned spatial variations in magma composition, the simplest explanation hitherto appears to be diachronous collision.

\section{CONCLUSION}

A field, petrologic and geochemical study of the Late Oligocene Takht batholith, Iran yields the following conclusions:
- The batholith was solidified at $\sim 25 \mathrm{Ma}$ and the depth of magma emplacement was likely $6.5 \mathrm{~km}$ or less. It consists mainly of intermediate to felsic rocks, showing subalkaline, dominantly metaluminous compositions and I-type affinity.

- The rocks display geochemical and Sr-Nd isotopic variations consistent with concurrent fractional crystallization and assimilation of lower to middle crustal rocks.

- The least evolved magma indicated by the data has intermediate composition, and might represent a differentiated liquid of a mantle-derived magma, or a partial melt of the lower crust, or any combination between them as predicted by models involving MASH or lower crustal hot zones.

- The batholith is most likely of Cordilleran-type related to northward subduction of the Neotethys. In the context of regional tectonics, the paleogeographic position of the batholith can be reconciled if Arabia and Eurasia have been colliding in a diachronous manner since the Late Eocene-Early Oligocene.

\section{DATA AVAILABILITY STATEMENT}

The original contributions presented in the study are included in the article/Supplementary Material, further inquiries can be directed to the corresponding authors.

\section{AUTHOR CONTRIBUTIONS}

K-NP analyzed the data and wrote the manuscript. AF designed the study, participated in field work, and analyzed the data. W-QJ obtained zircon U-Pb isotopic data and analyzed the data. SJ and AJ participated in field work. All authors contributed to the article and approved the submitted version.

\section{FUNDING}

Financial support from Urmia University (Iran), Ministry of Science and Technology, Taiwan, China (105-2628-M-001-002MY4 to K-NP), and Career Development Award, Academia Sinica (AS-CDA-109-M07 to K-NP) are acknowledged.

\section{ACKNOWLEDGMENTS}

The authors thank the reviewers for comments and suggestions, improving the presentation of many arguments. The authors also thank P. R. Castillo for editorial handling.

\section{SUPPLEMENTARY MATERIAL}

The Supplementary Material for this article can be found online at: $\quad$ https://www.frontiersin.org/articles/10.3389/feart.2020. 00354/full\#supplementary-material 


\section{REFERENCES}

Aftabi, A., and Atapour, H. (2000). Regional aspects of shoshonitic volcanism in Iran. Episodes 23, 119-125.

Ahmadian, J., Sarjoughian, F., Lentz, D., Esna-Ashari, A., Murata, M., and Ozawa, H. (2016). Eocene K-rich adakitic rocks in the Central Iran: implications for evaluating its $\mathrm{Cu}-\mathrm{Au}-\mathrm{Mo}$ metallogenic potential. Ore Geol. Rev. 72, 323-342. doi: 10.1016/j.oregeorev.2015.07.017

Alavi, M. (1994). Tectonic of the Zagros orogenic belt of Iran: new data and interpretations. Tectonophysics 229, 211-238. doi: 10.1016/0040-1951(94) 90030- 2

Aldanmaz, E., Pearce, J. A., Thirlwall, M. F., and Mitchell, J. G. (2000). Petrogenetic evolution of late Cenozoic, post-collision volcanism in western Anatolia, Turkey. J. Volcanol. Geotherm. Res. 102, 67-95. doi: 10.1016/s0377-0273(00) 00182-7

Allen, M. B., and Armstrong, H. A. (2008). Arabia-Eurasia collision and the forcing of mid-Cenozoic global cooling. Palaeogeogr. Palaeoclimatol. Palaeoecol. 265, 52-58. doi: 10.1016/j.palaeo.2008.04.021

Annen, C., Blundy, J. D., and Sparks, R. S. J. (2006). The genesis of intermediate and silicic magmas in deep crustal hot zones. J. Petrol. 47, 505-539. doi: 10.1093/petrology/egi084

Babazadeh, S., Ghorbani, M. R., Bröcker, M., D’Antonio, M., Cottle, J., Gebbing, T., et al. (2017). Late oligocene-miocene mantle upwelling and interaction inferred from mantle signatures in gabbroic to granitic rocks from the UrumiehDokhtar arc, south Ardestan, Iran. Int. Geol. Rev. 59, 1590-1608. doi: 10.1080/ 00206814.2017.1286613

Berberian, F., and Berberian, M. (1981). Tectono-plutonic episodes in Iran. Geol. Surv. Iran Rep. 52, 566-593.

Berberian, M., and King, G. C. P. (1981). Towards a paleogeography and tectonic evolution of Iran. Can. J. Earth Sci. 18, 210-265. doi: 10.1139/e81-019

Blatter, D. L., Sisson, T. W., and Hankins, W. B. (2013). Crystallization of oxidized, moderately hydrous arc basalt at mid- to lower-crustal pressures: implications for andesite genesis. Contrib. Mineral. Petrol. 166, 861-886. doi: 10.1007/ s00410-013-0920-3

Blundy, J. D., and Holland, T. J. B. (1990). Calcic amphibole equilibria and a new amphibole-plagioclase geothermometer. Contrib. Mineral. Petrol. 104, 208-224. doi: $10.1007 /$ bf00306444

Bohrson, W. A., and Spera, F. J. (2001). Energy-constrained open-system magmatic processes II: application of energy-constrained assimilationfractional crystallization (EC-AFC) model to magmatic systems. J. Petrol. 42, 1019-1041. doi: 10.1093/petrology/42.5.1019

Bonin, B., Janoušek, V., and Moyen, J.-F. (2020). Chemical variation, modal composition and classification of granitoids. Geol. Soc. Lond. Spec. Publ. 491, 9-51. doi: 10.1144/sp491-2019-138

Cawood, P. A., Hawkesworth, C. J., and Dhuime, B. (2013). The continental record and the generation of continental crust. Geol. Soc. Am. Bull. 125, 14-32. doi: 10.1130/b30722.1

Chapman, J. B., Ducea, M. N., DeCelles, P. G., and Profeta, L. (2015). Tracking changes in crustal thickness during orogenic evolution with $\mathrm{Sr} / \mathrm{Y}$ : an example from the North American Cordillera. Geology 43, 919-922. doi: 10.1130/ g36996.1

Chappell, B. W., and White, A. J. R. (1974). Two contrasting granite types. Pac. Geol. 8, 173-174.

Chiu, H.-Y., Chung, S.-L., Zarrinkoub, M. H., Mohammadi, S. S., Khatib, M. M., and Iizuka, I. (2013). Zircon U-Pb age constraints from Iran on the magmatic evolution related to Neotethyan subduction and Zagros orogeny. Lithos 162 163, 70-87. doi: 10.1016/j.lithos.2013.01.006

Chung, S.-L., Liu, D., Ji, J., Chu, M.-F., Lee, H.-Y., Wen, D.-J., et al. (2003). Adakites from continental collision zones: melting of thickened lower crust beneath southern Tibet. Geology 31, 1021-1024.

Corfu, F. (2013). A century of U-Pb geochronology: the long quest towards concordance. Geol. Soc. Am. Bull. 125, 33-47. doi: 10.1130/b 30698.1

Dargahi, S. (2007). Post-Collisional Miocene Magmatism in the SarcheshmehShahrebabak Region NW of Kerman: Isotopic Study, Petrogenetic Analysis and Geodynamic Pattern of Granitoid Intrusives and the Role of Adakitic Magmatism in Development of Copper Mineralization. $\mathrm{PhD}$ thesis. Kerman: Shahid Bahonar University of Kerman.
Dargahi, S., Arvin, M., Pan, Y., and Babaei, A. (2010). Petrogenesis of Post-collisional A-type granitoid from the Urumieh-Dokhtar magmatic assemblage, Southwestern Kerman, Iran: constraints on the ArabianEurasian continental collision. Lithos 115, 190-204. doi: 10.1016/j.lithos.2009. 12.002

Debon, F., and Le Fort, P. (1988). A cationic classification of common plutonic rocks and their magmatic associations: principles, method, applications. Bull. Minéral. 111, 493-510. doi: 10.3406/bulmi.1988.8096

DePaolo, D. J. (1981). Trace element and isotopic effects of combined wallrock assimilation and fractional crystallization. Earth Planet. Sci. Lett. 53, 189-202. doi: $10.1016 / 0012-821 x(81) 90153-9$

Dimitrijevic, M. D. (1973). Geology of the Kerman Region. Report 52. Tehran: Geological Survey of Iran.

Ducea, M. N., Saleeby, J. B., and Bergantz, G. (2015). The architecture, chemistry, and evolution of continental magmatic arcs. Annu. Rev. Earth Planet. Sci. 43, 299-331. doi: 10.1146/annurev-earth-060614-105049

Ersoy, Y., and Helvac1, C. (2010). FC-AFC-FCA and mixing modeler: a Microsoft ${ }^{\circledR}$ Excel $\odot$ spreadsheet program for modeling geochemical differentiation of magma by crystal fractionation, crustal assimilation and mixing. Comput. Geosci. 36, 383-390. doi: 10.1016/j.cageo.2009.06.007

Faure, G., and Mensing, T. M. (2005). Isotopes: Principles and Applications. Hoboken, NJ: John Wiley and Sons, 897.

Fazlnia, A. (2019). Petrogenesis and tectonic significance of Sardasht syenitemonzonite-gabbro-appinite intrusions, NW Iran. Int. J. Earth Sci. 108, 49-66. doi: 10.1007/s00531-018-1641-7

Fazlnia, A. N., Jamei, S., and Jafari, A. (2014). Penetrative conditions and tectonomagmatic setting of the Takht granitic batholith, Sirjan. Petrology 5, 33-50.

Förster, H.-J. (1998). The chemical composition of REE-Y-Th-U-rich accessory minerals in peraluminous granites of the Erzgebirge-Fichtelgebirge region, Germany. Part II: xenotime. Am. Mineral. 83, 1302-1315. doi: 10.2138/am1998-11-1219

Frost, B. R., Barnes, C. G., Collins, W. J., Arculus, R. J., Ellis, D. J., and Frost, C. D. (2001). A geochemical classification for granitic rocks. J. Petrol. 42, 2033-2048. doi: 10.1093/petrology/42.11.2033

Gholami Zadeh, P., Adabi, M. H., Hisada, K.-I., Hosseini-Barzi, M., Sadeghi, A., and Ghassemi, M. R. (2017). Revised version of the Cenozoic collision along the Zagros Orogen, insights from Cr-spinel and sandstone modal analyses. Sci. Rep. 7:10828.

Goss, A. R., Kay, S. M., and Mpodozis, C. (2013). Andean adakite-like high-Mg andesites on the northern margin of the Chilean-Pampean flat-slab $\left(27-28.5^{\circ} \mathrm{S}\right)$ associated with frontal arc migration and fore-arc subduction erosion. J. Petrol. 54, 2193-2234. doi: 10.1093/petrology/egt044

Hammarstrom, J. M., and Zen, E. (1986). Aluminum in hornblende: an empirical igneous geobarometer. Am. Mineral. 71, 1297-1313.

Hassanzadeh, J. (1993). Metallogenic and Tectono-Magmatic Events in the SE Sector of the Cenozoic Active Continental Margin of Iran (Shahr-e-Babak area, Kerman province). Ph.D. thesis. Los Angeles, CA: University of California.

Hassanzadeh, J., and Wernicke, B. P. (2016). The Neotethyan Sanandaj-Sirjan zone of Iran as an archetype for passive margin-arc transitions. Tectonics 35, 586-621. doi: 10.1002/2015tc003926

Hawkesworth, C. J., Cawood, P. A., Dhuime, B., and Kemp, T. I. S. (2017). Earth's continental lithosphere through time. Annu. Rev. Earth Planet. Sci. 45, 169-198. doi: 10.1146/annurev-earth-063016-020525

Hildreth, W., and Moorbath, S. (1988). Crustal contributions to arc magmatism in the Andes of Central Chile. Contrib. Mineral. Petrol. 98, 455-489. doi: 10.1007/bf00372365

Hollister, L. S., Grisson, G. C., Peters, E. K., Stowell, H. H., and Sisson, V. B. (1987). Confirmation of the empirical correlation of $\mathrm{Al}$ in hornblende with pressure of solidification of calc-alkaline plutons. Am. Mineral. 72, 231-239.

Honarmand, M., Rashidnejad Omran, N., Corfu, F., Hashem Emami, M., and Nabatian, G. (2013). Geochronology and magmatic history of a calc-alkaline plutonic complex in the Urumieh-Dokhtar Magmatic Belt, Central Iran: zircon ages as evidence for two major plutonic episodes. Neues Jahrbuch für Mineral. 190, 67-77. doi: 10.1127/0077-7757/2013/0230

Honarmand, M., Rashidnejad Omran, N., Neubauer, F., Nabatian, G., Hashem Emami, M., Bernroider, M., et al. (2016). Mineral chemistry of a Cenozoic igneous complex, the Urumieh-Dokhtar magmatic belt, Iran: petrological 
implications for the plutonic rocks. Island Arc 25, 137-153. doi: 10.1111/iar. 12148

Hosseini, M. R., Ghaderi, M., Alirezaei, S., and Sun, W. (2017a). Geological characteristics and geochronology of the Takht-e-Gonbad copper deposit, SE Iran: a variant of porphyry type deposits. Ore Geol. Rev. 86, 440-458. doi: 10.1016/j.oregeorev.2017.03.003

Hosseini, M. R., Hassanzadeh, J., Alirezaei, S., Sun, W., and Li, C.-Y. (2017b). Age revision of the neotethyan arc migration into the southeast Urumieh-Dokhtar belt of Iran: geochemistry and U-Pb zircon geochronology. Lithos 284-285, 296-309. doi: 10.1016/j.lithos.2017.03.012

Hu, F., Ducea, M. N., Liu, S., and Chapman, J. B. (2017). Quantifying crustal thickness in continental collisional belts: global perspective and a geologic application. Sci. Rep. 7:7058.

Ickert, R. B. (2013). Algorithms for estimating uncertainties in initial radiogenic isotope ratios and model ages. Chem. Geol. 340, 131-138. doi: 10.1016/j. chemgeo.2013.01.001

Jagoutz, O., Macdonald, F. A., and Royden, L. (2016). Low-latitude arc-continent collision as a driver for global cooling. Proc. Natl. Acad. Sci. U.S.A. 113, 4935-4940. doi: 10.1073/pnas.1523667113

Ji, W.-Q., Wu, F.-Y., Liu, C.-Z., and Chung, S.-L. (2012). Early Eocene crustal thickening in southern Tibet: new age and geochemical constraints from the Gangdese batholith. J. Asian Earth Sci. 53, 82-95. doi: 10.1016/j.jseaes.2011. 08.020

Ji, W.-Q., Wu, F.-Y., Wang, J.-M., Liu, X.-C., Liu, Z.-C., Zhang, Z., et al. (2020). Early evolution of himalayan orogenic belt and generation of middle eocene magmatism: constraint from Haweng granodiorite porphyry in the tethyan himalaya. Front. Earth Sci. 8:236. doi: 10.3389/feart.2020. 00236

Johnson, M. C., and Rutherford, M. J. (1989). Experimental calibration of an aluminum-in-hornblende geobarometer applicable to Long Valley caldera (California) volcanic rocks. Geology 17, 837-841.

Kananian, A., Sarjoughian, F., Nadimi, A., Ahmadian, J., and Ling, W. (2014). Geochemical characteristics of the Kuh-e Dom intrusion, Urumieh-Dokhtar Magmatic Arc (Iran): implications for source regions and magmatic evolution. J. Asian Earth Sci. 90, 137-148. doi: 10.1016/j.jseaes.2014.04.026

Khan-Nazer, N. A., and Emami, H. (1996). Geological Map of Chahar Gonbad (scale: 1:100000). Tehran: Geological Survey of Iran.

Koshnaw, R. I., Stockli, D. F., and Schlunegger, F. (2018). Timing of the Arabia-Eurasia continental collision - evidence from detrital zircon U-Pb geochronology of the Red Bed Series strata of the northwest Zagros hinterland, Kurdistan region of Iraq. Geology 47, 47-50. doi: 10.1130/g45499.1

Kouhestani, H., Ghaderi, M., Emami, M. H., Meffre, S., Kamenetsky, V., McPhie, J., et al. (2017). Compositional characteristics and geodynamic significance of late Miocene volcanic rocks associated with the Chah Zard epithermal gold-silver deposit, southwest Yazd, Iran. Island Arc 27:e12223. doi: 10.1111/iar.12223

Leake, B. E., Woolley, A. R., Arps, C. E. S., Birch, W. D., Gilbert, M. C., Grice, J. D., et al. (1997). Nomenclature of amphiboles; report of the subcommittee on amphiboles of the international mineralogical association, commission on new minerals and mineral names. Am. Mineral. 82, 1019-1037.

Lee, C.-T. A., and Bachmann, O. (2014). How important is the role of crystal fractionation in making intermediate magmas? Insights from $\mathrm{Zr}$ and $\mathrm{P}$ systematics. Earth Planet. Sci. Lett. 393, 266-274. doi: 10.1016/j.epsl.2014. 02.044

Lin, Y.-C., Chung, S.-L., Bingöl, A. F., Yang, L., Okrostsvaridze, A., Pang, K.N., et al. (2020). Diachronous initiation of post-collisional magmatism in the Arabia-Eurasia collision zone. Lithos 356-357, 105394. doi: 10.1016/j.lithos. 2020.105394

Ludwig, K. R. (1998). On the treatment of concordant uranium-lead ages. Geochim. Cosmochim. Acta 62, 665-676. doi: 10.1016/s0016-7037(98)00059-3

McInnes, B. I. A., Evans, N. J., Fu, F. Q., and Garwin, S. (2005). Application of thermochronology to hydrothermal ore deposits. Rev. Mineral. Geochem. 58, 467-498. doi: 10.1515/9781501509575-020

McQuarrie, N., and van Hinsbergen, D. J. J. (2013). Retrodeforming the ArabiaEurasia collision zone: age of collision versus magnitude of continental subduction. Geology 41, 315-318. doi: 10.1130/g33591.1

Mohajjel, M., and Fergusson, C. L. (2014). Jurassic to Cenozoic tectonics of the Zagros Orogen in northwestern Iran. Int. Geol. Rev. 56, 263-287. doi: 10.1080/ 00206814.2013 .853919
Moritz, R., Rezeau, H., Ovtcharova, M., Tayan, R., Melkonyan, R., Hovakimyan, S., et al. (2016). Long-lived, stationary magmatism and pulsed porphyry systems during Tethyan subduction to post-collision evolution in the southernmost Lesser Caucasus, Armenia and Nakhitchevan. Gondwana Res. 37, 465-503. doi: 10.1016/j.gr.2015.10.009

Mouthereau, F., Lacombe, O., and Vergés, J. (2012). Building the Zagros collisional orogen: timing, strain distribution and the dynamics of Arabia/Eurasia plate convergence. Tectonophysics 532-535, 27-60. doi: 10.1016/j.tecto.2012. 01.022

Moyen, J.-F., Laurent, O., Chelle-Michou, C., Couzinié, S., Vanderhaeghe, O., Zeh, A., et al. (2017). Collision vs. subduction-related magmatism: two contrasting ways of granite formation and implications for crustal growth. Lithos 277, 154-177. doi: 10.1016/j.lithos.2016.09.018

Nouri, F., Azizi, H., Stern, R. J., Asahara, Y., Khodaparast, S., Madanipour, S., et al. (2018). Zircon U-Pb dating, geochemistry and evolution of the Late Eocene Saveh magmatic complex, central Iran: partial melts of sub-continental lithospheric mantle and magmatic differentiation. Lithos 314-315, 274-292. doi: 10.1016/j.lithos.2018.06.013

Omrani, J., Agard, P., Whitechurch, H., Benoit, M., Prouteau, G., et al. (2008). Arc-magmatism and subduction history beneath the Zagros Mountains, Iran: a new report of adakites and geodynamic consequences. Lithos 106, 380-398. doi: 10.1016/j.lithos.2008.09.008

Pang, K.-N., Chung, S.-L., Zarrinkoub, M. H., Wang, F., Kamenetsky, V. S., and Lee, H.-Y. (2015). Quaternary high-Mg ultrapotassic rocks from the Qal'eh Hasan Ali maars, southeastern Iran: petrogenesis and geodynamic implications. Contribut. Mineral. Petrol. 170:27.

Profeta, L., Ducea, M. N., Chapman, J. B., Paterson, S. R., Marisol Henriquez, Gonzales, S., et al. (2015). Quantifying crustal thickness over time in magmatic arcs. Sci. Rep. 5:17786.

Putirka, K. (2016). Amphibole thermometers and barometers for igneous systems and some implications for eruption mechanisms of felsic magmas at arc volcanoes. Am. Mineral. 101, 841-858. doi: 10.2138/am-2016-5506

Rasouli, J., Ghorbani, M., Ahadnejad, V., and Poli, G. (2016). Calk-alkaline magmatism of Jebal-e-Barez plutonic complex, SE Iran: implication for subduction-related magmatic arc. Arab. J. Geosci. 9, 287-306.

Rezeau, H., Moritz, R., Leuthold, J., Hovakimyan, S., Tayan, R., and Chiaradia, M. (2017). 30 Myr of Cenozoic magmatism along the Tethyan margin during Arabia-Eurasia accretionary orogenesis (Meghri-Ordubad pluton, southernmost Lesser Caucasus). Lithos 288-289, 108-124. doi: 10.1016/j.lithos. 2017.07.007

Rezeau, H., Moritz, R., Wotzlaw, J.-F., Tayan, R., Melkonyan, R., Ulianov, A., et al. (2016). Temporal and genetic link between incremental pluton assembly and pulsed porphyry Cu-Mo formation in accretionary orogens. Geology 44, 627-630. doi: 10.1130/g38088.1

Sarjoughian, F., Kananian, A., Haschke, M., Ahmadian, J., and Ling, W. (2012). Magma mingling and hybridization in the Kuh-e Dom pluton, Central Iran. J. Asian Earth Sci. 54-55, 49-63. doi: 10.1016/j.jseaes.2012. 03.013

Sarjoughian, F., Lentz, D., Kananian, A., Ao, S., and Xiao, W. (2018). Geochemical and isotopic constraints on the role of juvenile crust and magma mixing in the UDMA magmatism, Iran: evidence from mafic microgranular enclaves and cogenetic granitoids in the Zafarghand igneous complex. Int. J. Earth Sci. 107, 1127-1151. doi: 10.1007/s00531-017-1548-8

Schmidt, M. W. (1992). Amphibole composition in tonalite as a function of pressure: an experimental calibration of the Al-in-hornblende barometer. Contrib. Mineral. Petrol. 110, 304-310. doi: 10.1007/bf00310745

Shafaii Moghadam, H., Khademi, M., Hu, Z., Stern, R. J., Santos, J. F., and Wu, Y. (2015). Cadomian (Ediacaran-Cambrian) arc magmatism in the ChahJamBiarjmand metamorphic complex (Iran): magmatism along the northern active margin of Gondwana. Gondwana Res. 27, 439-452. doi: 10.1016/j.gr.2013. 10.014

Shafiei, B. (2008). Metallogenic Model of Kerman Porphyry Copper Belt and its Exploratory Approaches. Ph.D. thesis. Kerman: Shaheed Bahonar University of Kerman.

Shafiei, B., Haschke, M., and Shahabpour, J. (2009). Recycling of orogenic arc crust triggers porphyry $\mathrm{Cu}$ mineralization in Kerman Cenozoic arc rocks, southeastern Iran. Mineral. Depos. 44, 265-283. doi: 10.1007/s00126-0080216-0 
Shahabpour, J. (2005). Tectonic evolution of the orogenic belt in the region located between Kerman and Neyriz. J. Asian Earth Sci. 24, 405-417. doi: 10.1016/j. jseaes.2003.11.007

Shahabpour, J. (2007). Island-arc affinity of the Central Iranian volcanic belt. J. Asian Earth Sci. 30, 652-665. doi: 10.1016/j.jseaes.20 07.02.004

Sláma, J., Košler, J., Condon, D. J., Crowley, J. L., Gerdes, A., Hanchar, J. M., et al. (2008). Plešovice zircon-a new natural reference material for $\mathrm{U}-\mathrm{Pb}$ and $\mathrm{Hf}$ isotopic microanalysis. Chem. Geol. 249, 1-35. doi: 10.1016/j.chemgeo.2007. 11.005

Spera, F. J., and Bohrson, W. A. (2001). Energy-constrained open-system magmatic processes I: general model and energy-constrained assimilation and fractional crystallization (EC-AFC) formulation. J. Petrol. 42, 999-1018. doi: 10.1093/ petrology/42.5.999

Stöcklin, J. (1968). Structural history and tectonics of Iran: a review. Am. Assoc. Petrol. Geol. Bull. 52, 1229-1258.

Sun, S.-S., and McDonough, W. F. (1989). "Chemical and isotopic systematics in ocean basalt: implication for mantle composition and processes," in Magmatism in the Ocean Basins. Geological Society of London Special Publications 42, eds A. D. Saunders and M. J. Norry (Oxford: Blackwell Scientific Publication), 313-345. doi: 10.1144/gsl.sp.1989.042.01.19

Topuz, G., Altherr, R., Schwarz, W. H., Siebel, W., Satır, M., and Dokuz, A. (2005). Post-collisional plutonism with adakite-like signatures: the Eocene Sarayclk granodiorite (Eastern Pontides, Turkey). Contrib. Mineral. Petrol. 150, 441-455. doi: 10.1007/s00410-005-0022-y

Verdel, C., Wernicke, B. P., Hassanzadeh, J., and Guest, B. (2011). A Paleogene extensional arc flare-up in Iran. Tectonics 30:TC3008. doi: 10.1029/ 2010TC002809
Vermeesch, P. (2018). IsoplotR: a free and open toolbox for geochronology. Geosci. Front. 9, 1479-1493. doi: 10.1016/j.gsf.2018.04.001

Wang, Y., Foley, S. F., and Preleviæ, D. (2017). Potassium-rich magmatism from a phlogopite-free source. Geology 45, 467-470. doi: 10.1130/g38691.1

Whitney, D. L., and Evans, B. (2010). Abbreviations for names of rock-forming minerals. Am. Mineral. 95, 185-187. doi: 10.2138/am.2010.3371

Yeganehfar, H., Ghorbani, M. R., Shinjo, R., and Ghaderi, M. (2013). Magmatic and geodynamic evolution of Urumieh-Dokhtar basic volcanism, Central Iran: major, trace element, isotopic, and geochronologic implications. Int. Geol. Rev. 55, 767-786. doi: 10.1080/00206814.2012.752554

Yin, A., and Harrison, T. M. (2000). Geologic evolution of the Himalayan-Tibetan orogen. Annu. Rev. Earth Planet. Sci. 28, 211-280. doi: 10.1146/annurev.earth. 28.1.211

Zarasvandi, A., Rezaei, M., Raith, J. G., Pourkaseb, H., Asadi, S., Saed, M., et al. (2018). Metal endowment reflected in chemical composition of silicates and sulfides of mineralized porphyry copper systems, Urumieh-Dokhtar magmatic arc, Iran. Geochim. Cosmochim. Acta 223, 36-59. doi: 10.1016/j.gca.2017.11.012

Conflict of Interest: The authors declare that the research was conducted in the absence of any commercial or financial relationships that could be construed as a potential conflict of interest.

Copyright (c) 2020 Pang, Fazlnia, Ji, Jamei and Jafari. This is an open-access article distributed under the terms of the Creative Commons Attribution License (CC BY). The use, distribution or reproduction in other forums is permitted, provided the original author(s) and the copyright owner(s) are credited and that the original publication in this journal is cited, in accordance with accepted academic practice. No use, distribution or reproduction is permitted which does not comply with these terms. 